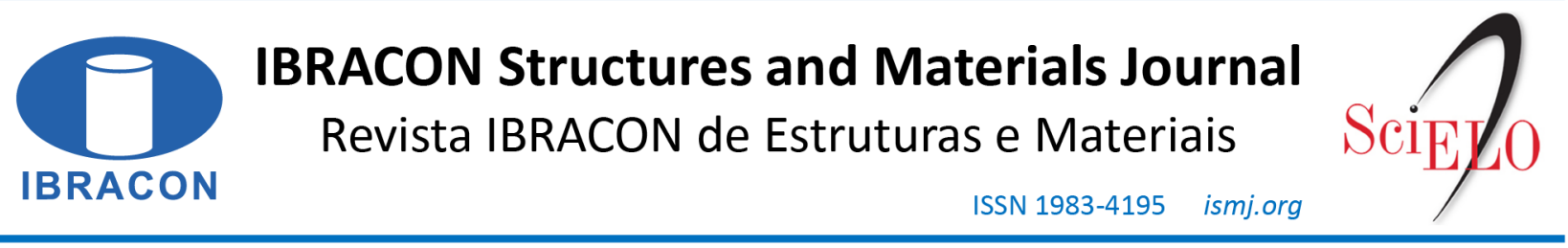

ORIGINAL ARTICLE

\title{
Fatigue safety level provided by Brazilian design standards for a prestressed girder highway bridge
}

\section{Nível de segurança à fadiga proporcionado pelas normas brasileiras de projeto em relação à uma ponte rodoviária com longarinas protendidas}

\author{
Anselmo Leal Carneiro ${ }^{a}$ \\ Enson de Lima Portela ${ }^{\mathrm{b}}$ \\ Túlio Nogueira Bittencourt ${ }^{\mathrm{c}}$ \\ André Teófilo Beck ${ }^{\mathrm{d}}$ (it)
}

\author{
${ }^{a}$ Universidade Federal do Rio de Janeiro - UFRJ, Campus Macaé, Macaé, RJ, Brasil \\ 'Instituto Federal do Ceará - IFCE, Departamento de Construção Civil, Fortaleza, CE, Brasil \\ ${ }^{c}$ Universidade de São Paulo - USP, Escola Politécnica, São Paulo, SP, Brasil \\ ${ }^{\mathrm{d}}$ Universidade de São Paulo - USP, Escola de Engenharia de São Carlos, São Carlos, SP, Brasil
}

Received 15 April 2020

Accepted 02 December 2020

\begin{abstract}
It is well known that highway bridges are subjected to fatigue as they work under live loads with different frequencies and amplitude. The safety level for fatigue required by Brazilian codes is still unknown, especially for prestressed concrete girders. Also, current studies on fatigue reliability of bridges only evaluate bending. This work assesses the fatigue safety level provided by Brazilian design standards for a concrete highway bridge, using weigh-in-motion (WIM) data of an important federal Brazilian highway, BR-381 (Fernão Dias Highway). The Palmgren-Miner rule is considered to evaluate the service life and reliability indexes, from the fatigue point of view, of prestressed girders designed according to Brazilian codes. Using limited and complete prestressing levels, different traffic volumes are considered. It is found that the fatigue safety levels of longitudinal and transverse reinforcements are larger than the ones recommended by the international literature.
\end{abstract}

Keywords: fatigue, highway bridges, concrete girders, weigh-in-motion, safety assessment.

\begin{abstract}
Resumo: As pontes rodoviárias, por receberem um carregamento variável proveniente do tráfego de veículos, são suscetíveis ao fenômeno de fadiga. O nível de segurança à fadiga proporcionado pelas normas brasileiras, porém, ainda é desconhecido, especialmente em relação às pontes com longarinas protendidas. Além disso, as publicações sobre confiabilidade à fadiga em pontes de concreto consideram apenas análise à flexão. Este trabalho avalia o nível de segurança à fadiga que as normas brasileiras de projeto proporcionam para uma ponte rodoviária de concreto, utilizando dados de pesagem em movimento (weigh-in-motion - WIM) de uma importante rodovia federal brasileira, a BR-381 (Rodovia Fernão Dias). Mediante a regra de Palmgren-Miner, avalia-se a vida útil e os índices de confiabilidade, sob o aspecto da fadiga, das longarinas protendidas dimensionadas conforme as normas brasileiras. Utiliza-se a protensão limitada e completa e consideram-se diferentes volumes de tráfego. Verifica-se que os níveis de segurança à fadiga das armaduras longitudinais e transversais são maiores que aqueles recomendados pela literatura internacional.
\end{abstract}

Palavras-chave: fadiga, pontes rodoviárias, longarinas de concreto, pesagem em movimento, avaliação da segurança.

How to cite: A. L. Carneiro, E. L. Portela, T. N. Bittencourt, and A. T. Beck, "Fatigue safety level provided by Brazilian design standards for a prestressed girder highway bridge," Rev. IBRACON Estrut. Mater., vol. 14, no. 4, e14415, 2021, https://doi.org/.10.1590/S198341952021000400015 


\section{INTRODUCTION}

Fatigue occurs due to stress fluctuations from in-service variable loads that, after a certain number of cycles, may lead to fracture of the material. From the point of view of the loads, fatigue is a Service Limit State - SLS and, from the resistance point of view, it has a character of Ultimate Limit State - ULS. In highway bridges, the number of stress cycles from the traffic determines the fatigue life of the structure. From the design point of view, fatigue is verified considering live load models.

The current Brazilian live load model as in NBR 7188 [1] is shown in Figure 1. This model was originally adopted from the Germany code, as stated by Pfeil [2]. By that time, the Germany live load model was an analogy of a war tank and a platoon crossing the bridge. As the current Brazilian code still uses this model, the procedure developed by Rüsch to estimate the load effect on bridge slabs are still valid and can be applied for the Brazilian live load model. It can be seen from Figure 1 that the contact area of the wheel with the pavement is $0.1 \mathrm{~m}^{2}$. According to Brazilian code, the live load model must be weighted by a coefficient related to impact, number of lanes and additional safety coefficients as in NBR 8681 [3]. For fatigue verification in girders, it requires use of a coefficient $\psi_{1 \text {,fad }}=0.5$ for spans lengths up to 100 meters.

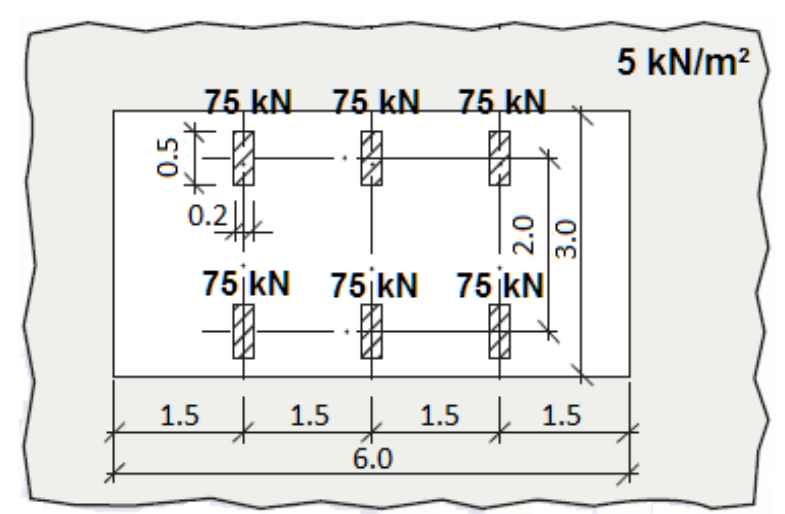

Figure 1. Brazilian live load model, dimension in meters (adapted from NBR 7188 [1]).

Carneiro et al. [4] evaluated the live load model as in NBR 7188 [1], from the unlimited fatigue life point of view, using traffic data from two HS-WIM stations in Brazil (BR-381 and BR-290) and proposed a new fatigue live load model for unlimited fatigue life. The authors indicated that the bias factor of the Brazilian model can vary a lot and may not correspond to the infinite fatigue life approach. Other studies on the assessment of current Brazilian live load model for bridges using real traffic data, are related only to ULS, as seen in Portela [5]. Thus, the reliability indexes of concrete bridges designed with the current Brazilian live load model, especially for prestressed girders, are still unknown in terms of fatigue.

With that in mind, this work assesses the fatigue safety level provided by Brazilian design standards in relation to a concrete highway bridge, using weigh-in-motion (WIM) data of an important federal Brazilian highway, BR-381 (the same data used in Carneiro et al. [4]). The fatigue service life and fatigue reliability indexes for a design life of 50 years are evaluated for prestressed concrete girders designed according to Brazilian codes, in terms of bending moment, shear force and torsion. The cumulative linear damage method, also known as the Palmgren-Miner rule, is considered. For the probabilistic analysis, the Latin Hypercube Sampling - LHS simulation method and the First-Order Reliability Method - FORM, are used. It is important to mention that this paper does not assess the safety of an existing bridge, which real monitoring is more appropriate, but it presents a methodology to evaluate the fatigue safety level provided by design standards.

\section{FATIGUE SAFETY ASSESSMENT}

\subsection{Literature review of fatigue reliability in concrete bridges}

Crespo-Minguillón and Casas [6] present a probabilistic model for fatigue analysis in prestressed bridges. The model uses the S-N curves and the Palmgren-Miner rule to define fatigue strength of reinforcing and prestressing steel. Using 
traffic data, they assessed the reliability of a slab bridge in terms of bending. They concluded that from the fatigue life point of view the bridge failure was unlikely to occur.

Rodrigues et al. [7] evaluated the fatigue reliability indexes of two-girder concrete bridges in Brazil. Only shortspan $(7 \mathrm{~m}, 10 \mathrm{~m}$ and $13 \mathrm{~m})$ bridges were considered in terms of ULS and fatigue. It is important to note, however, that this structural solution, widely used in Brazil over the past years, is no longer the common application in current bridge design. They used traffic data from a static weighing station in São Paulo, from 2005, measured for 204 days. The work concluded that the safety levels, especially in relation to fatigue, are lower than desired. The study only performed bending analysis and the methodology was based on the work of Crespo-Minguillón and Casas [6].

Wassef et al. [8] calibrated the partial safety factors for SLS and fatigue in relation to concrete bridges in the United States. They used data from fifteen different WIM stations around the country, measured for one year. The authors used the infinite fatigue life approach and considered only girder bending.

Yan et al. [9] presented a methodology for assessing the fatigue reliability of short span bridges subjected to real traffic. The authors applied the methodology on a girder and determined the fatigue reliability indexes of longitudinal reinforcements.

Other works like Junges [10], Wang et al. [11], Mankar et al. [12] and [13] presented methodologies and casestudies to assess the fatigue reliability of monitored bridges. Junges [10] measured stress in two Brazilian reinforced concrete bridges and concluded that flexural reinforcement failure is unlikely to occur. Wang et al. [11] also evaluated flexural reinforcement of concrete girders. Mankar et al. [12] and [13] evaluated concrete bridge slabs in terms of fatigue in concrete and reinforcement, respectively. In Mankar et al. [12] the authors used test data to present stochastic models of S-N curves for concrete in compression. In an extensive literature review, no work was found on fatigue reliability assessment of stirrups.

\subsection{Fatigue resistance}

In order to determine the fatigue strength, the S-N curve is used. This curve is a plot of the magnitude of an alternating stress $(\mathrm{S})$ and the number of cycles to failure $(\mathrm{N})$ for a given material, as shown in Equation 1. Figure 2 depicts the curve of Equation 1 in logarithmic scale. The parameters of reinforcement S-N curves from fib [14] model code are shown in Table 1.

$N . \Delta \sigma^{m}=K$

where $m$ and $K$ : material-related constants; $N$ : number of cycles to failure; $\Delta \sigma:$ stress range.

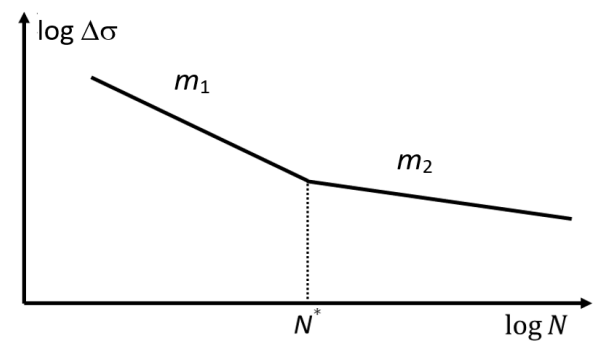

Figure 2. S-N curves for reinforcement (adapted from fib [14] and NBR 6118 [15]]).

Table 1. Parameters of characteristic S-N curves from fib [14].

\begin{tabular}{|c|c|c|c|c|c|c|}
\hline Case & $m_{1}$ & $m_{2}$ & $\begin{array}{c}\Delta \sigma_{R s k}(\mathrm{MPa}) \text { at } N^{*} \\
=\mathbf{1 0}^{6} \text { cycles }\end{array}$ & $\begin{array}{c}\Delta \sigma_{R s k}(\mathbf{M P a}) \text { at } \\
\mathbf{1 0}^{8} \text { cycles } \\
\end{array}$ & $K_{1}=N x \Delta \sigma^{m 1}$ & $K_{2}=N x \Delta \sigma^{m 2}$ \\
\hline $\begin{array}{l}\text { Reinforcing steel (straight bars } \\
\left.\qquad \phi_{\mathrm{s}} \leq 16 \mathrm{~mm}\right)\end{array}$ & 5 & 9 & 210 & 125 & $4.08 \times 10^{17}$ & $7.45 \times 10^{26}$ \\
\hline $\begin{array}{c}\text { Prestressing steel } \\
\text { (postensioning curved tendons) }\end{array}$ & 3 & 7 & 120 & 65 & $1.73 \times 10^{12}$ & $4.90 \times 10^{20}$ \\
\hline
\end{tabular}

Note: $m_{1}, m_{2}$ and $N^{*}$ are indicated in Figure 2 and $\Delta \sigma_{R s k}$ is the characteristic stress range. 
To determine the fatigue strength of bent bars with mandrel diameter " $\mathrm{D}$ " lower than $25 \phi_{\mathrm{s}}$, where $\phi_{\mathrm{s}}$ is the bar diameter, the model code indicates multiplication of straight bar values by a reduction factor $\xi=0.35+0.026 \mathrm{D} / \phi_{\mathrm{s}}$, also proposed by EN 1992-1-1 [16]. The standards, however, do not make clear if the values obtained with the reduction factor should be used for stirrups.

According to Plos et al. [17], the fatigue strength of bent bars is reduced because the steel undergoes plastic deformation through bending, leading to microcracks. The smaller the bending radius of curvature, the smaller is the fatigue strength. The report adds that bending of stirrups is an exception since tests revealed that, in most cases, stirrups fail in the straight part, due to shear; thus, outside the bent zone. This can also be verified in Higgins et al. [18], [19] and Bachman et al. [20]. Thus, Souza et al. [21] indicate that straight bar S-N curves can be used for stirrups. Hillebrand and Hegger [22] and Hillebrand et al. [23] conducted experimental tests on prestressed concrete beams and also verified that stirrups fail in the straight part.

NBR 6118 [15] considers a reduction factor to determine the fatigue strength of stirrups. Because of this, the design of stirrups for bridge girders, following the Brazilian standard, is usually governed by fatigue. This is not the case for the design of longitudinal reinforcements. The standard considers the stress related to $2 \times 10^{6}$ cycles for fatigue design verification. For straight bars (reinforcing steel) and stirrups, with diameters up to $16 \mathrm{~mm}$, these values are $\Delta_{\text {fsd,fad }}=190$ $\mathrm{MPa}$ and $\Delta_{\text {fsd,fad }}=85 \mathrm{MPa}$, respectively. The value for straight bars is in accordance with the S-N curve from fib [14] (194 MPa for $2 \times 10^{6}$ cycles). The value of $85 \mathrm{MPa}$ corresponds to the application of the reduction factor $\xi$ with $\mathrm{D}=3 \phi_{\mathrm{s}}$ to the straight bar value $(194 \times 0.428 \approx 85)$. For the fatigue design verification, the partial safety factor for steel is 1.0 (characteristic stress).

\subsection{Fatigue Damage}

For variable stress amplitudes, the cumulative fatigue damage calculation may be performed according to the Palmgren-Miner rule, as in Equation 2. In this linear damage rule the failure occurs when the damage reaches a value known as Miner damage at failure $(D M)$.

Damage $=\sum_{i} \frac{q_{i}}{N_{i}} \leq D M$

where $q_{i}$ : number of cycles obtained from the load spectra for each stress range amplitude; $N_{i}$ : number of cycles relative to the failure for each stress range amplitude (obtained from the S-N curve).

Theoretically, Miner damage at failure $(D M)$ should be equal to one. However, as it is an empirical rule, critical damage observed in practice is a random variable. For deterministic analysis, $D M=1$ is generally considered.

\subsection{Fatigue service-life estimation}

Considering the fatigue damage related to a one-year load spectra and $D M=1$ in Equation 2 (deterministic analysis), the fatigue service life, in years, may be estimated based on Equation 3.

$T_{F}=\frac{1}{\text { Damage }_{(1 \text { year })}}$

where $T_{F}$ : Fatigue service life; Damage $_{(1 \text { year })}=\Sigma\left(q_{i} / N_{i}\right)$ for one year, where $q_{i}$ and $N_{i}$ are presented in Section 2.3.

\subsection{Probabilistic analysis for fatigue}

Crespo-Minguillón and Casas [6] consider the Weibull distribution to represent fatigue strength (number of cycles to failure) randomness. The expressions for the probability density function, $f_{N}(n)$ and cumulative distribution function, $F_{N}(n)$ are given as: 
$f_{N}(n)=\frac{\alpha}{u-n_{0}} \cdot\left(\frac{n-n_{0}}{u-n_{0}}\right)^{\alpha-1} \cdot \exp \left[-\left(\frac{n-n_{0}}{u-n_{0}}\right)^{\alpha}\right], n \geq n_{0}$

$F_{N}(n)=1-\exp \left[-\left(\frac{n-n_{0}}{u-n_{0}}\right)^{\alpha}\right], n \geq n_{0}$

where $\alpha$ : shape parameter; $u$ : scale parameter; $n_{0}$ : lower limit (this value is always 0.0 for strictly positive variables, such as the fatigue strength).

Considering $n_{0}=0$, the relationship between moments (mean and variance) and parameters is given by Equations 6 and 7 , where $\Gamma()$ represents the Gamma function.

$\mu_{N}=u \Gamma\left(1+\frac{1}{\alpha}\right)$

$\sigma_{N}^{2}=u^{2}\left[\Gamma\left(1+\frac{2}{\alpha}\right)-\Gamma^{2}\left(1+\frac{1}{\alpha}\right)\right]$

For $\mu_{N}$ e $\sigma_{N}^{2}$ determined experimentally, the shape parameter $\alpha$ can be determined iteratively by Equation 8 , as reported by Melchers and Beck [24]. With the value of $\alpha$, the scale parameter $u$ may be determined from Equation 6 .

$1+\left(\frac{\sigma_{N}}{\mu_{N}}\right)^{2}=\frac{\Gamma\left(1+\frac{2}{\alpha}\right)}{\Gamma^{2}\left(1+\frac{1}{\alpha}\right)}$

For the fatigue safety assessment, based on Palmgren-Miner rule, the limit state function, as mentioned by CrespoMinguillón and Casas [6], is given by:

$G(\boldsymbol{X})=D M-\sum_{i} \frac{1}{N_{i}}$

where $x$ : vector of random variables involved (the random variables are indicated in Table 6, as described in Sections 4 and 5); $D M$ : Miner damage at failure, which is the resistance variable; $1 / \mathrm{N}_{\mathrm{i}}$ : elementary damage due to each stress range cycle from the load spectra; $\sum\left(1 / \mathrm{N}_{\mathrm{i}}\right)$ : damage due to the load spectra for the reference period considered (50 years or 100 years, normally, for the design service life of bridges), which is the load effect variable.

According to Weibull distribution, Crespo-Minguillón and Casas [6] present S-N curves for reinforcing steel (straight bars) and prestressing steel (posttensioning curved tendons) for a 50\% confidence level, as indicated in Table 2. In this paper, several simulations of the random variables are performed and different values of $\sum\left(1 / \mathrm{N}_{\mathrm{i}}\right)$ are calculated using the S-N curves from Table 2. Then, the probability distribution, moments and parameters of the dependent variable $\sum\left(1 / \mathrm{N}_{\mathrm{i}}\right)$ are obtained.

As reported by Crespo-Minguillón and Casas [6], the randomness of $D M$ comes from the randomness of S-N curves. The authors present parameters for Miner damage variable in tests characterized by constant-amplitude stress cycles for reinforcing steel (straight bars) and prestressing steel (posttensioning curved tendons) for different S-N intervals $\left(D M_{i}\right.$ in Table 3). 
Table 2. Parameters of S-N curves for a 50\% confidence level (adapted from Crespo-Minguillón and Casas [6]).

\begin{tabular}{ccccc}
\hline Case & $\Delta \boldsymbol{\sigma}$ (MPa) & $\boldsymbol{N}$ & $\boldsymbol{m}=\boldsymbol{N} \boldsymbol{\Delta} \sigma^{\boldsymbol{m}}$ \\
\hline & $\geq 245$ & $\leq 2 \times 10^{6}$ & 6 & $4.33 \times 10^{20}$ \\
\cline { 2 - 4 } Reinforcing steel (straight bars) & $<245$ & $>2 \times 10^{6}$ & 9 & $6.39 \times 10^{27}$ \\
\cline { 2 - 4 } & $>205$ & $<10^{7}$ & 11 & $2.69 \times 10^{32}$ \\
\hline $\begin{array}{c}\text { Prestressing steel (postensioning } \\
\text { curved tendons) }\end{array}$ & $\leq 205$ & $>10^{7}$ & 3 & $165^{3} \times 10^{6}$ \\
\hline & $<165$ & $\leq 10^{6}$ & 7 & $165^{7} \times 10^{6}$ \\
\hline
\end{tabular}

Table 3. Parameters of variable $D M_{i}$ (adapted from Crespo-Minguillón and Casas [6]).

\begin{tabular}{|c|c|c|c|c|c|}
\hline Case & $\Delta \sigma(\mathbf{M P a})$ & Mean & Standard deviation & $\alpha$ & $u$ \\
\hline \multirow{4}{*}{ Reinforcing steel (straight bars) } & $\geq 245$ & 1.104 & 0.463 & 2.57 & 1.24 \\
\hline & $<245$ & \multirow{2}{*}{1.154} & \multirow{2}{*}{0.556} & \multirow{2}{*}{2.19} & \multirow{2}{*}{1.30} \\
\hline & $>205$ & & & & \\
\hline & $\leq 205$ & 1.169 & 0.618 & 1.97 & 1.32 \\
\hline \multirow{2}{*}{$\begin{array}{l}\text { Prestressing steel (postensioning } \\
\text { curved tendons) }\end{array}$} & $\geq 165$ & 1.041 & 0.274 & 4.28 & 1.14 \\
\hline & $<165$ & 1.072 & 0.367 & 3.21 & 1.20 \\
\hline
\end{tabular}

For a spectrum of variable amplitude stress cycles, the parameters of $D M$ for the limit state function (9) can be obtained with the weighting of $D M_{i}$ related to the damage for each interval of stress range, as reported by CrespoMinguillón and Casas [6] and Rodrigues et al. [7]. Therefore, in order to acquire the parameters of $D M$ for (9), related to all stress ranges, the following procedure can be applied:

- For each simulation of the random variables (Table 6$)$, the percentages of $\sum\left(1 / \mathrm{N}_{\mathrm{i}}\right)$ corresponding to each interval of stress range (limits in Tables 2 and 3) are obtained;

- At the end of all simulations, the average percentages of $\sum\left(1 / \mathrm{N}_{\mathrm{i}}\right)$ corresponding to each interval for all simulations are obtained;

- By simulation, for each interval, several $D M_{i}$ values are generated, compatible with the respective weighting (average percentage);

- With the $D M_{i}$ values for all the intervals, the probabilistic distribution and the parameters of the $D M$ variable are evaluated.

In this paper, the simulations are performed using the Latin Hypercube Sampling - LHS simulation technique, which permit to obtain reasonable results with a reduced number of simulations. With the parameters of the variables of the limit state function, the FORM method is used, within StRAnD (Beck [31]), to calculate the reliability indexes. The LHS and FORM can be verified in Melchers and Beck [24] and Nowak and Collins [32].

\section{WEIGH-IN-MOTION - WIM}

\subsection{Description of the system and WIM station}

Regarding the relevance of actual traffic, this work uses vehicle records obtained from a high-speed weigh-inmotion (HS-WIM) station, as shown in Figure 3. The system is installed on road lanes, and vehicles are registered with no need to stop or to lower their speeds. In general, the system consists of lines of piezoelectric sensors, inductive loops, temperature sensors and a device to collect and analyze the records. Inductive loops detect vehicles, measure the distance between axles and speed, while piezoelectric sensors are responsible for weighting. 
In this work, the data from the BR-381 (Fernão Dias Highway, which connects the states of São Paulo and Minas Gerais) station is used (same data used in Carneiro et al. [4]). The system is installed in two road lanes in the same direction (Minas Gerais to São Paulo), as indicated in Figure 3c. For each vehicle that passes over the sensors, the system provides information such as day, hour, lane, speed, total length, total weight, axle spacing and axle weight. The system was installed in July 2015 and the station remained in operation until 2019. The HS-WIM system avoids evasion, as drivers do not notice it. In addition, due to the continuous process of obtaining data ( 24 hours a day, on consecutive days), the system also yields the real frequency of vehicle occurrences, which is essential for fatigue analysis. These particularities give the technology a great advantage over static weighing stations. In the static weighing process, overloaded vehicles can trace alternative routes, the multiple presence occurrences are unknown, and the data is not collected 24 hours a day, in days and months in a row.

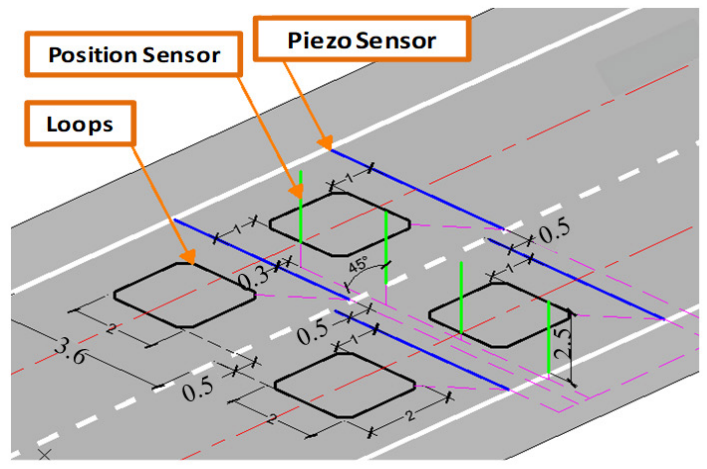

a)

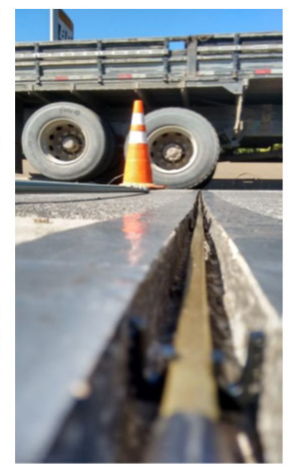

b)

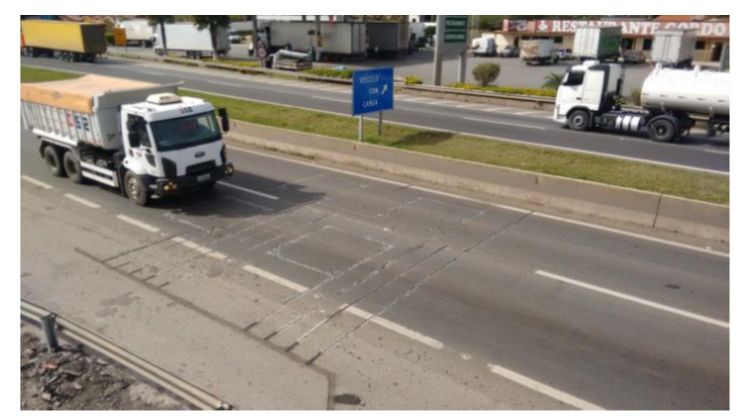

c)

Figure 3. HS-WIM system: a) layout and sensors position [4], [5]; b) weighting sensor before grout in BR-381 [4], [5], [33]; c) final appearance of the pavement in BR-381 [5], [33] (position sensors, which detect when vehicles change lanes, was not installed).

As WIM sensors are strongly influenced by temperature variation, the system must undergo periodic calibrations. In these measurements, a truck of known weight passes through the sensors at varying speeds, at different times of the day. From July 2015 to August 2017, five calibrations were conducted on the WIM system in BR-381 (July 2015, October 2015, February 2016, February 2017 and May 2017). The error, in relation to the total weight of the trucks, is around 10\%. In Brazil, considering the reduced number of WIM stations, the use of this system is not common.

\subsection{Filtering process and traffic characteristics}

Even with calibrations, the system might present incorrect measurements: weights greater than the maximum traction capacity, or smaller than the self-weight, are some examples. Furthermore, several data are unnecessary for the study of live load for bridges. Passenger vehicles and light trucks, for instance, can be neglected, in most analyses, due to irrelevant load effect on the bridge. Thus, WIM data needs to be filtered before it can be used.

The filtering criteria need to be defined considering the characteristics of the Brazilian fleet and may vary according to the analysis need, in other words ULS, SLS or fatigue. Among the 14 criteria used in Wassef et al. [8], one filter eliminates trucks with total weight less than $90 \mathrm{kN}$. As reported by Laranjeiras [34], trucks weighing less than $70 \mathrm{kN}$ accumulate fatigue damage that is irrelevant to the safety of the structure, even if they occur many times. 
The following list presents, in order, the filters that were applied to the station considered. The filters were set after a research of National Department of Transportation resolutions (DNIT [35]-[37]) and truck manufacturers catalogs. Vehicles that fit any of the filters have been excluded.

1- GVW $\leq \mathbf{6 2} \mathbf{~ k N}$ (GVW is the total gross vehicle weight). This limit is set based on the maximum physical limit of GVW of lightweight two axle truck (veiculo semi-leve in Portuguese). This criterion has the objective of removing irrelevant light trucks.

2- $\mathbf{P i} \leq \mathbf{2 2} \mathbf{~ k N}$, where "Pi" is the axle weight. This value represents the steering axle load of maximum GVW of lightweight two axle trucks.

3- Pd $>320$ kN, where "Pd" is the weight referring to the double tandem. This limit is set based on the heaviest axle weight of a double tandem found in the catalogs of truck manufactures in Brazil. This filter also contributes to eliminate records with GVW greater than the maximum traction capacity of the vehicle. For the sake of comparison, the legal limit for double tandem according to Brazilian regulations is $170 \mathrm{kN}$.

4- $\mathbf{d i} \leq \mathbf{0 . 9 2} \mathbf{~ m}$, where "di" is the distance between axles. In Brazil, the minimum wheel diameter for a tandem was found to be 0.87 meters. Adding the wheel spacing of 0.05 meters, the final minimum distance between axles is 0.92 meters.

5- $\mathbf{C}>\mathbf{3 6} \mathbf{~ m}$, where "C" is the total length of the vehicle. In Brazil, the maximum length allowed is 30 meters. On top of this value, an error margin was considered.

6- $\mathrm{C}>15.4 \mathrm{~m}$ and $\mathrm{GVW} \leq \mathbf{1 0 4 . 3} \mathrm{kN}$. This filter screens out the unrealistic long and light trucks, and possible considerations of two trucks in following position as a single unit. The length is defined based on the 14-meter trucks (common in Brazil), with a margin of error of $10 \%$. The GVW is defined based on the sum between $42.3 \mathrm{kN}$ (axle with lower carrying capacity of a 14-meter truck) and $62 \mathrm{kN}$ (minimum GVW for the other truck according to Filter 1).

7- $\mathbf{P i}>180 \mathrm{kN}$. Among all catalogs that were investigated, the maximum carrying capacity (physical limit) of a single axle was found to be $180 \mathrm{kN}$. This filter also contributes to eliminate records with GVW greater than the maximum traction capacity of the vehicle. For the sake of comparison, Brazilian legislation established the weight limit of single axles in $100 \mathrm{kN}$.

8- GVW $\geq \mathbf{1 . 1} \sum \mathbf{P i}$ or GVW $\leq \mathbf{0 . 9} \sum \mathbf{P i}$, where " $\sum \mathrm{Pi}$ " represents the sum of the weights of the axles. This criterion considers a margin of error of $10 \%$ on total weights.

9- $\sum \mathbf{d i}>\mathbf{C}$, where " $\sum$ di" represents the sum of axle spacings. This filter eliminates incorrect data of the wheelbase or the truck length.

10- $\mathbf{C}<\mathbf{5} \mathbf{~ m}$. This filter eliminates incorrect truck length data.

11- V $>170 \mathrm{Km} / \mathbf{h}$, where "V" is the vehicle speed. As in Brazil there are records of trucks traveling at $160 \mathrm{Km} / \mathrm{h}$, the value of $170 \mathrm{Km} / \mathrm{h}$ was set as a limit. It should be mentioned that the occurrence of such events is rare.

12- P1 > $\mathbf{1 0 0 ~ k N , ~ w h e r e ~ " P 1 " ~ i s ~ t h e ~ w e i g h t ~ o f ~ t h e ~ f i r s t ~ a x l e ~ ( f r o n t ) . ~ A c c o r d i n g ~ t o ~ t r u c k ~ m a n u f a c t u r e r s ~ c a t a l o g s ~ t h i s ~ v a l u e ~}$ is the maximum carrying capacity of the first axle.

13- GVW $>1500 \mathbf{~ k N}$. This limit is set based on the maximum carrying capacity found in catalogs, which corresponds to a nine-axle truck.

To determine the traffic load effect, WIM station data from September 2016 to May 2017 (273 days), is taken into account. It was found that use of a longer period of data does not significantly change the results.

Before filtering, the average daily traffic is 13292 . After filtering, only $27 \%$ of the entire sample is considered as valid trucks. The first and second filters are responsible for filtering out $68 \%$ and $3.5 \%$ of the records, respectively. The other filters together eliminate only $1.5 \%$ of the records. It is worth mentioning that Filter 8 did not exclude any records. This indicates that the measurements of weights (total and individual per axle) are consistent. Filter eleven removes only one truck per month on average. Filters 3 and 7 eliminate less than one truck per day on average (0,3 for Filter 3 and 0,8 for Filter 7).

In this paper, the records are analyzed using Microsoft Excel spreadsheets. After filtering, the Average Daily Truck Traffic (ADTT) is 3655, where 83\% of trucks are on the right lane (slow lane). The ADTT varies from 1079 to 5103 . Table 4 shows some statistics for twelve most frequent classes, which represents $95 \%$ of the data after filtering, and the respective legal weights ( $5 \%$ of tolerance). It is worth pointing out, nevertheless, that a possible reduction in the values of Filters 1 and 2 would change the statistics of two-axle truck 2C (DNIT class). The maximum GVW obtained are higher than the limits imposed by Brazilian law.

The maximum GVW obtained was $1193 \mathrm{kN}$, corresponding to nine-axle truck 3M6 (DNIT class). Figure 4 shows the histogram for GVW for class 3M6 and Figures 5 to 7 show the histogram for weights for first axle, double tandem and triple tandem, respectively, for class 3M6. Figure 8 shows the histogram for weights for a single axle for class $3 \mathrm{I} 3$ 
(DNIT class), which is the heaviest class with single axles in Table 4. Based on the histograms presented, it is noted that the maximum weights obtained do not reach the values of filters $3,7,12$ or 13 .

To assess the sensitivity of Filter 1 in relation to the safety analysis, the value of $62 \mathrm{kN}$ was changed to $90 \mathrm{kN}$, as used in Wassef et al. [8]. It was found that the results presented in Section 5 did not change, that is, the value of $62 \mathrm{kN}$ is shown to be sufficient and may even be increased to eliminate a larger number of trucks, unnecessary for the analysis.

Table 4. Statistics for twelve most frequent classes of BR-381 from September 2016 to May 2017.

\begin{tabular}{|c|c|c|c|c|}
\hline Silhouette & Class (DNIT) & Frequency $(\%)$ & GVW (kN) & Legal GVW (kN) \\
\hline & \multirow{3}{*}{$2 \mathrm{C}$} & \multirow{3}{*}{14.96} & 62.0 (min.) & \multirow{3}{*}{168.0} \\
\hline & & & 272.5 (max.) & \\
\hline & & & 100.8 (aver.) & \\
\hline & \multirow{3}{*}{$2 \mathrm{~S} 1$} & \multirow{3}{*}{1.89} & 69.9 (min.) & \multirow{3}{*}{273.0} \\
\hline & & & 359.8 (max.) & \\
\hline & & & 154.2 (aver.) & \\
\hline & \multirow{3}{*}{$3 \mathrm{C}$} & \multirow{3}{*}{23.33} & 66.7 (min.) & \multirow{3}{*}{242.0} \\
\hline & & & 417.1 (max.) & \\
\hline & & & 166.7 (aver.) & \\
\hline & \multirow{3}{*}{$2 \mathrm{~S} 2$} & \multirow{3}{*}{13.03} & 99.3 (min.) & \multirow{3}{*}{347.0} \\
\hline & & & 497.4 (max.) & \\
\hline & & & 190.9 (aver.) & \\
\hline & \multirow{3}{*}{$2 \mathrm{I} 2$} & \multirow{3}{*}{2.05} & 100.1 (min.) & \multirow{3}{*}{378.0} \\
\hline & & & 529.6 (max.) & \\
\hline & & & 196.8 (aver.) & \\
\hline & \multirow{3}{*}{$4 \mathrm{CD}$} & \multirow{3}{*}{2.68} & 96.0 (min.) & \multirow{3}{*}{305.0} \\
\hline & & & 504.1 (max.) & \\
\hline & & & 242.8 (aver.) & \\
\hline & \multirow{3}{*}{$2 \mathrm{~S} 3$} & \multirow{3}{*}{9.45} & 124.2 (min.) & \multirow{3}{*}{436.0} \\
\hline & & & 704.5 (max.) & \\
\hline & & & 325.1 (aver.) & \\
\hline & \multirow{3}{*}{$3 \mathrm{~S} 2$} & \multirow{3}{*}{1.98} & 128.2 (min.) & \multirow{3}{*}{420.0} \\
\hline & & & 630.1 (max.) & \\
\hline & & & 260.0 (aver.) & \\
\hline & \multirow{3}{*}{$3 \mathrm{~S} 3$} & \multirow{3}{*}{14.77} & 139.8 (min.) & \multirow{3}{*}{509.3} \\
\hline & & & 869.2 (max.) & \\
\hline & & & 414.6 (aver.) & \\
\hline & \multirow{3}{*}{$3 \mathrm{I} 3$} & & 143.1 (min.) & \\
\hline & & 3.13 & 760.2 (max.) & 556.5 \\
\hline & & & 448.0 (aver.) & \\
\hline & & & 183.3 (min.) & \\
\hline & $3 \mathrm{D} 4$ & 4.5 & 1026.1 (max.) & 599.0 \\
\hline & & & 502.1 (aver.) & \\
\hline & & & 240.8 (min.) & \\
\hline$\Rightarrow$ & $3 \mathrm{M} 6$ & 2.68 & 1192.7 (max.) & 777.0 \\
\hline & & & 660.2 (aver.) & \\
\hline
\end{tabular}

Notes: GVW is the Gross Vehicle Weight; Legal GVW considers 5\% of tolerance; min.: minimum; max.: maximum; aver.: average 


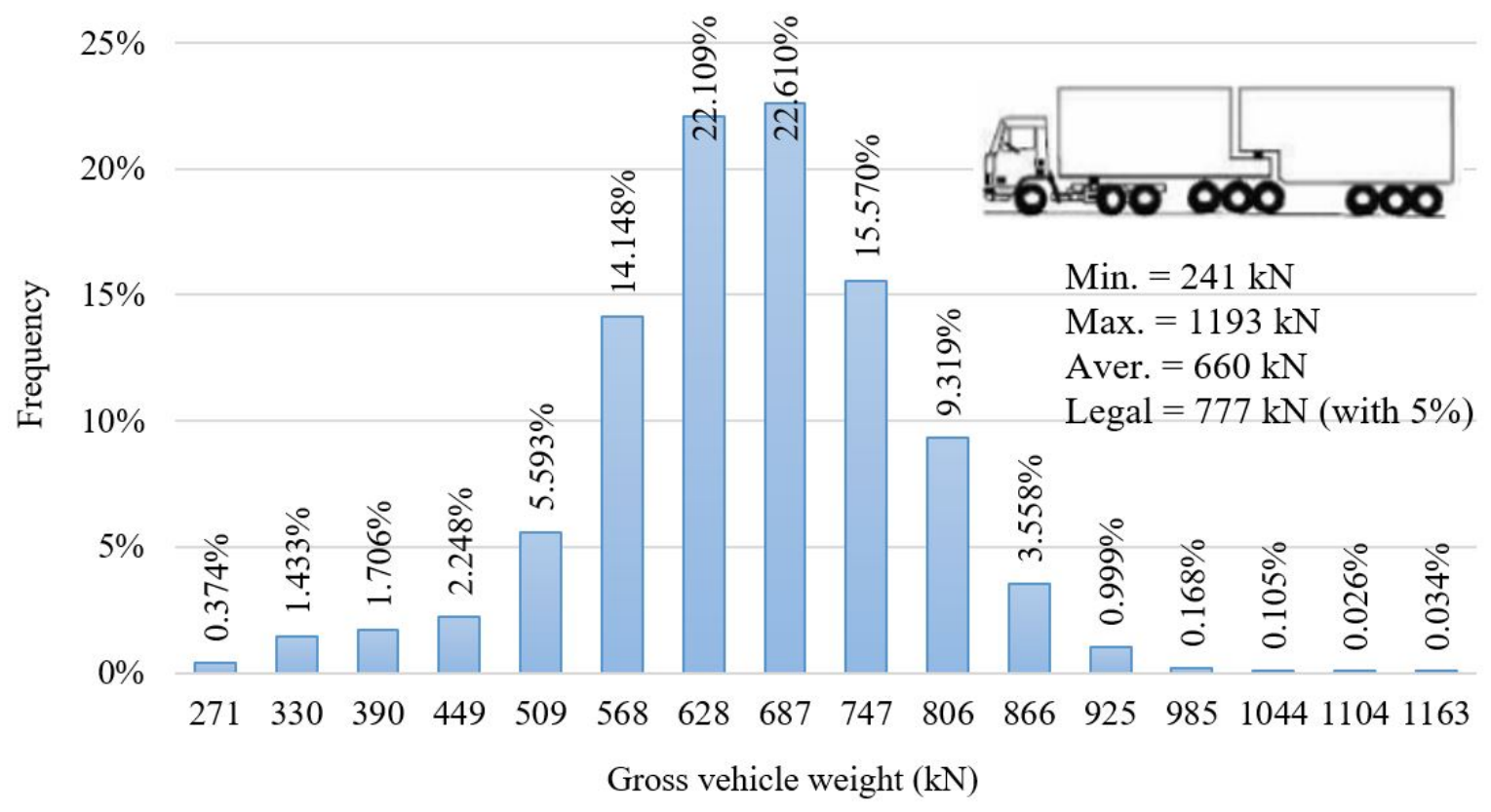

Figure 4. Histogram for GVW for class 3M6 (the horizontal axis shows the average values for each interval).

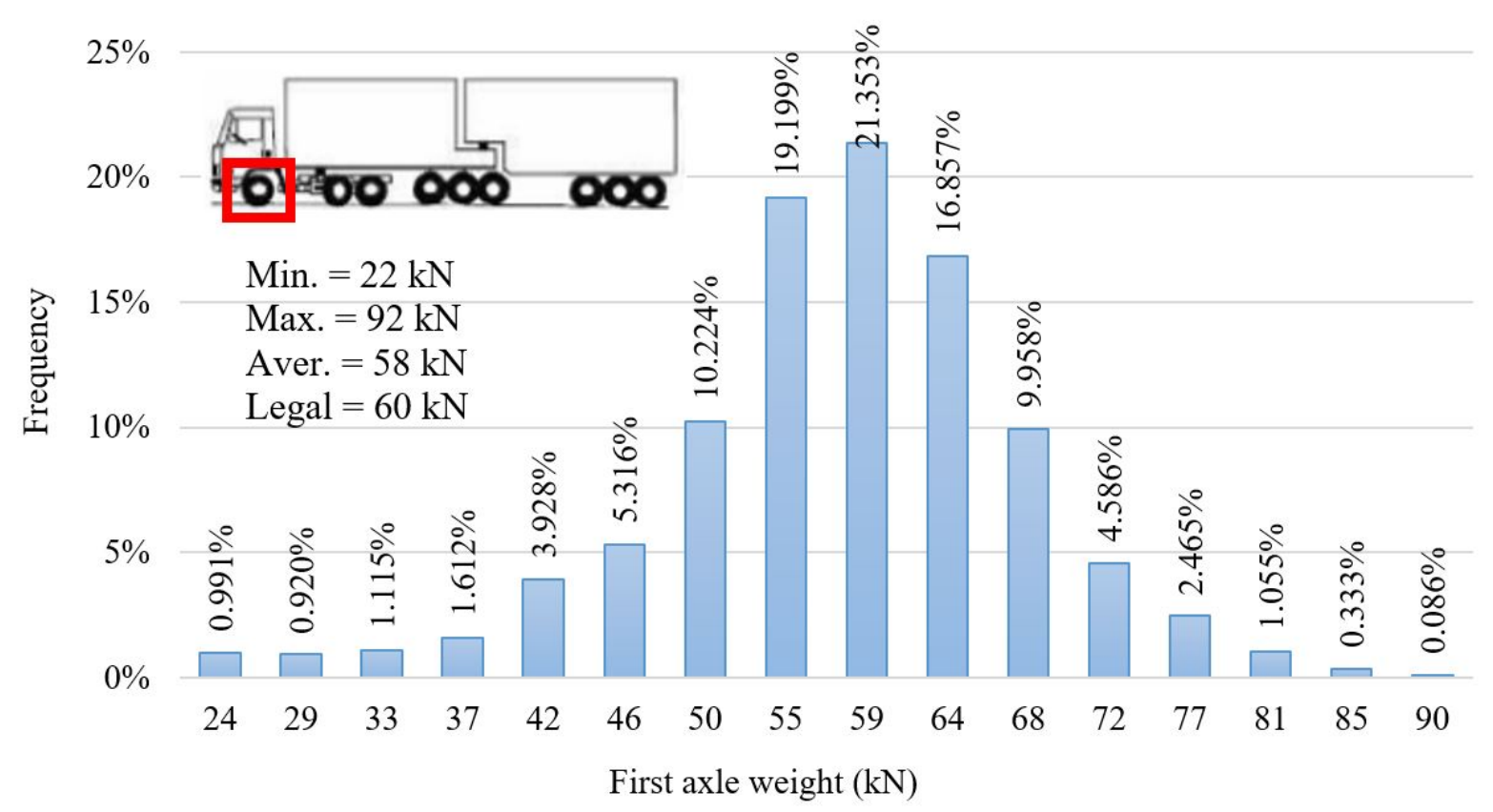

Figure 5. Histogram for weight for first axle for class 3M6 (the horizontal axis shows the average values for each interval). 


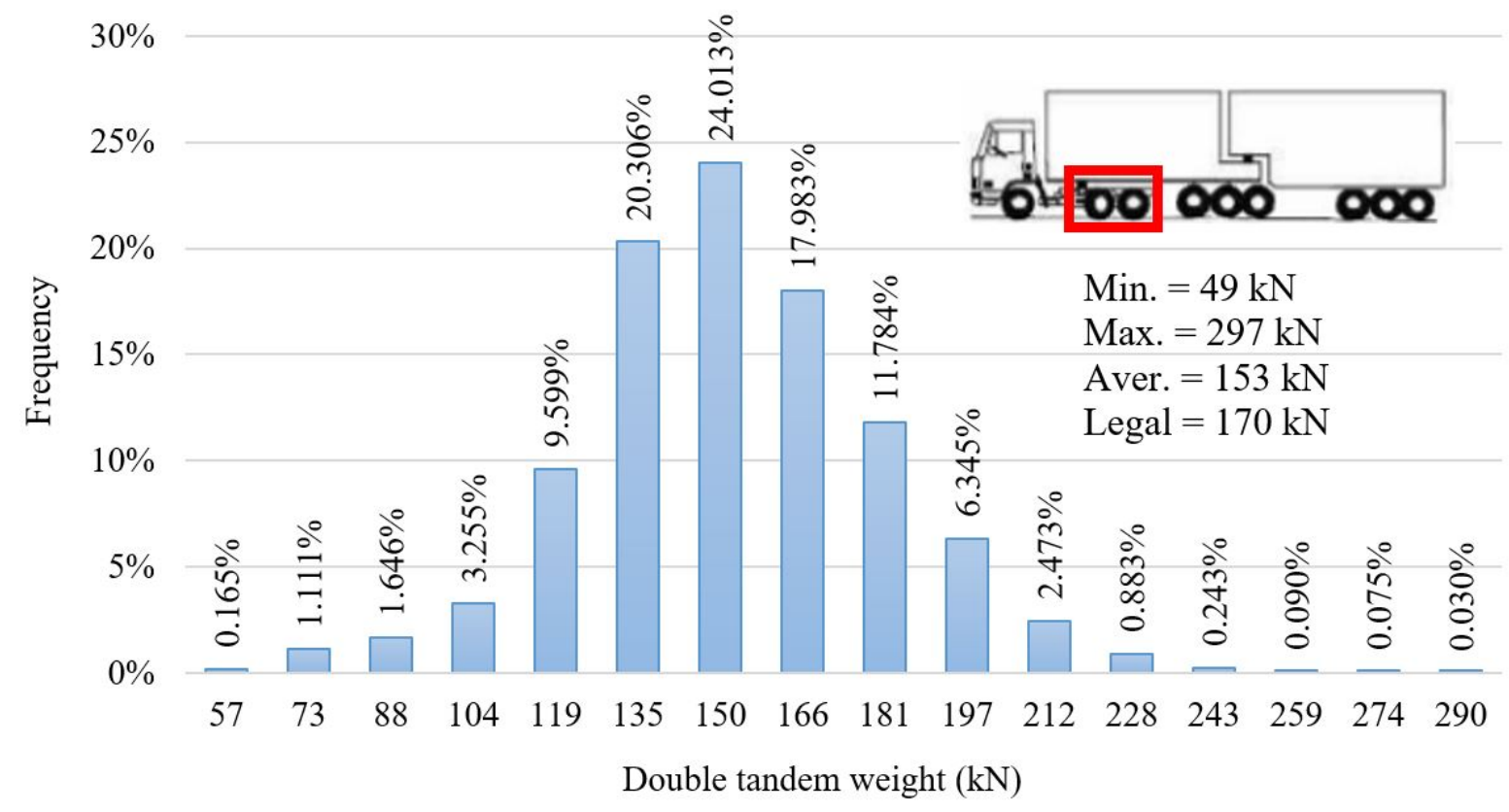

Figure 6. Histogram for weight for double tandem for class 3M6 (the horizontal axis shows the average values for each interval).

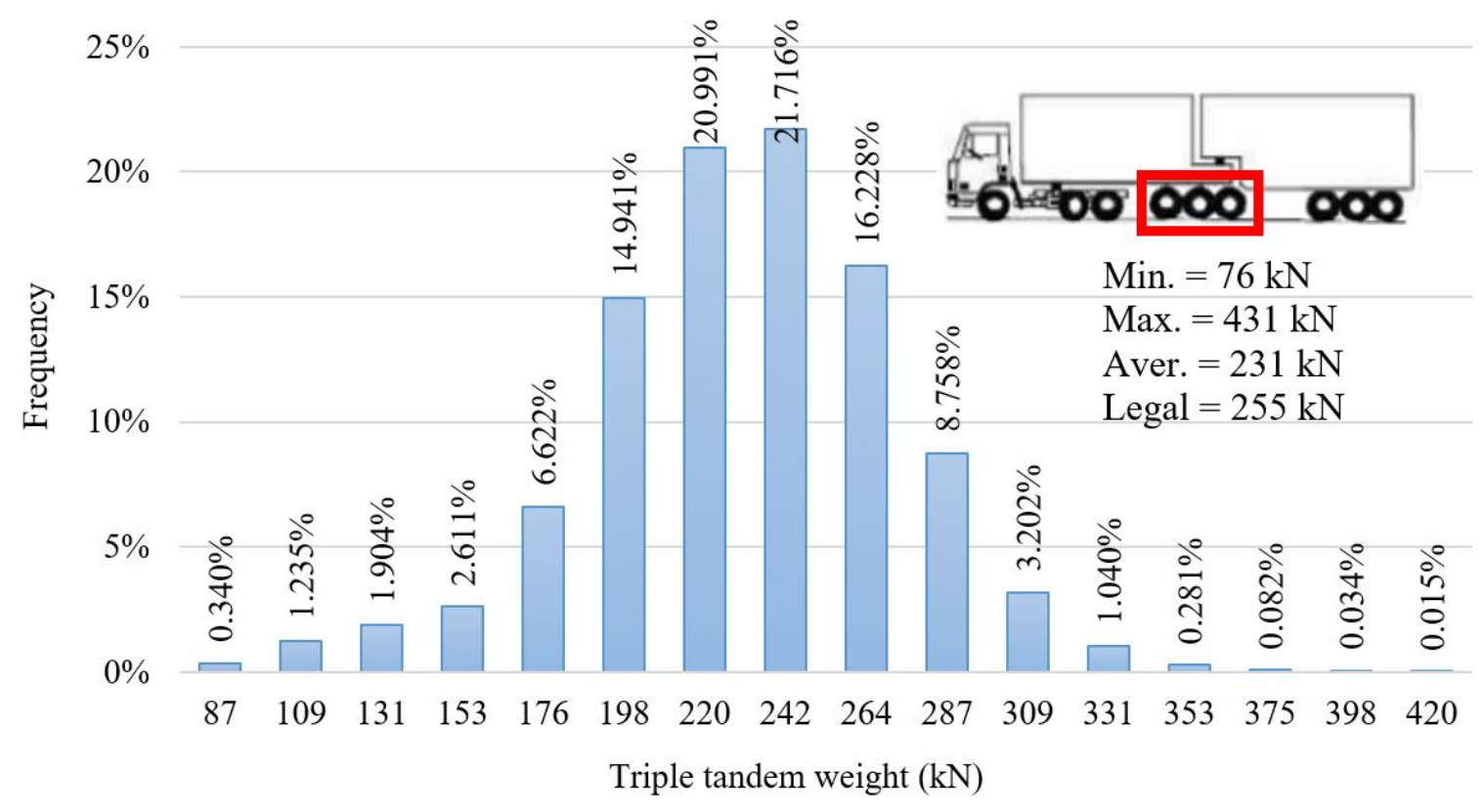

Figure 7. Histogram for weight for triple tandem for class 3M6, which the horizontal axis shows the average values for each interval (the histogram for both triple tandem are similar). 


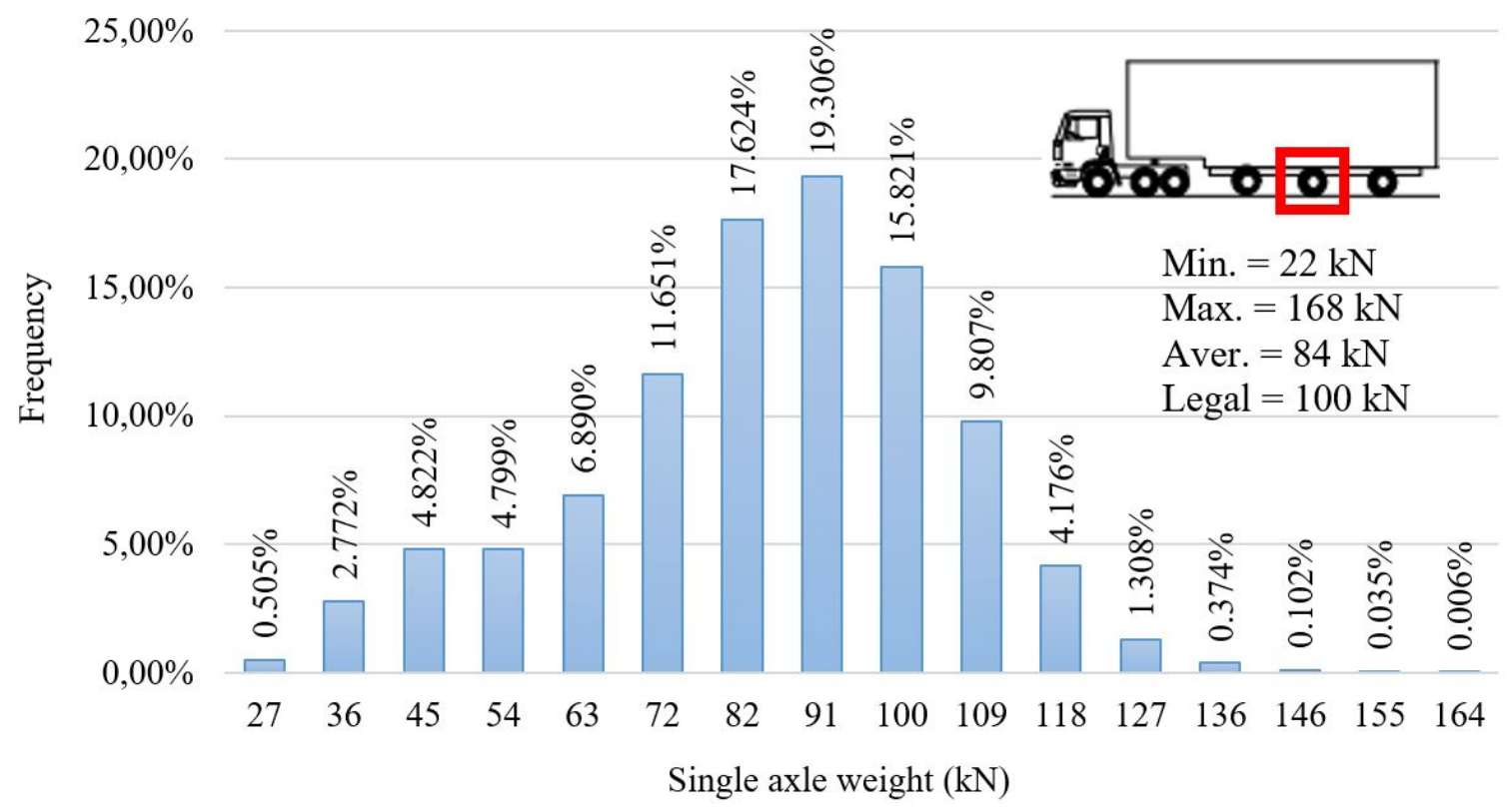

Figure 8. Histogram for weight for single axle for class 3I3, which the horizontal axis shows the average values for each interval (the histogram for single axles for $3 \mathrm{I} 3$ are similar).

\section{EVALUATED BRIDGE AND TRAFFIC STRESS RANGE IN THE REINFORCEMENT}

\subsection{Evaluated bridge}

This work evaluates the fatigue safety of the bridge girders illustrated in Figure 9. The dimensions were obtained from a real bridge that has a simply supported span of 28 meters and crossbeams only on supports. The girders are designed based on the Brazilian Design Standards, considering the ULS, SLS and Fatigue Limit States. The same reinforcement detailing for all girders is considered, i.e., the greatest rebar areas are considered.

The transverse load distribution is performed according to the Fauchart's method, using the Ftool program (Martha [38]). The method, which can be verified in Stucchi and Skaf [39], is also used for the traffic load effect. For the pavement, a total load of $3.2 \mathrm{kN} / \mathrm{m}^{2}$ is considered ( $5 \mathrm{~cm}$ of pavement with weight of $24 \mathrm{kN} / \mathrm{m}^{3}$ and an additional load of $2 \mathrm{kN} / \mathrm{m}^{2}$ for paving improvements). Two possibilities are considered for the design, one with limited prestressing and another with complete prestressing level. Prestressing losses are considered as $25 \%$. The Additional Impact Coefficient (CIA, in Portuguese) of NBR 7188 [1] is not computed in the design, since the coefficient should be only applied to slabs and crossbeams in the vicinity of the joints.

\section{CROSS-SECT [ON (MIDSPAN):}

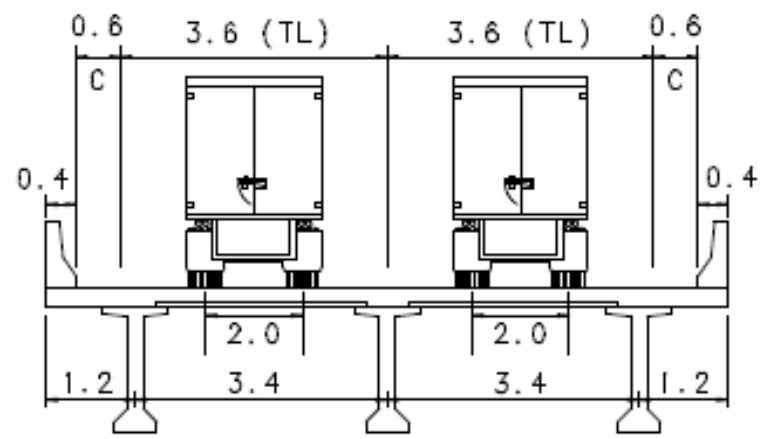

NOTES :

$\mathrm{TL}=$ TRAFFIC LANE

$C=$ CLEARANCE

D]MENSIONS IN METERS

Figure 9. Bridge section. 
The stirrups design, about the ULS and fatigue, consider the combination of shear force with torsional moment. It is important to observe, however, that the maximum shear and torsion for design are not simultaneous. The section close to the support without web enlargement, indicated in Figure 10, even with shear smaller than the section adjacent to the support, show the greatest stress range for stirrups in fatigue verification and the largest calculated area of transverse reinforcement. The calculated reinforcement area for stirrups for ULS (section indicated in Figure 10) needed to be increased to meet fatigue assessment, that is, the stirrups design was controlled by fatigue. Flexural fatigue analysis did not affect the areas of longitudinal reinforcement.

The NBR 6118 [15] provides two models for transverse reinforcement design based on the truss model. In Model I, the strut angle assumes a fixed value of 45 degrees; whereas in Model II, this angle may vary from 30 to 45 degrees. Furthermore, the portion of the shear force resisted by complementary mechanisms of the truss model differs from one model to another. Based on the standards equations, it is noticeable that Model II is more refined, while Model I is simpler. For the studied bridge, Model II with an angle of 30 degrees led to smaller areas for transverse reinforcement (reduction of around 15\%, comparing to Model I). Thus, Model II is adopted in design, to obtain the smallest possible reliability indexes, according to design prescriptions by NBR 6118 [15].

The girder dimensions are indicated in Figure 10, and the calculated reinforcement areas are shown in Table 5. The compressive strength of concrete at 28 days $\left(\mathrm{f}_{\mathrm{ck}}\right)$ is $40 \mathrm{MPa}$ for precast beams and $30 \mathrm{MPa}$ for slabs. The yield stress of reinforcing steel $\left(f_{\mathrm{yk}}\right)$ is $500 \mathrm{MPa}$. The strength $\left(\mathrm{f}_{\mathrm{ptk}}\right)$ and yield stress $\left(\mathrm{f}_{\mathrm{pyk}}\right)$ of prestressing steel are 1900 and $1710 \mathrm{MPa}$, respectively. The modules of elasticity for reinforcing and prestressing steel are 210 and $200 \mathrm{GPa}$, respectively, as indicated by NBR 6118 [15]. The secant modulus of elasticity of concrete is given as a function of $\mathrm{f}_{\mathrm{ck}}$, as indicated by NBR 6118 [15], and granite is considered as coarse aggregate.
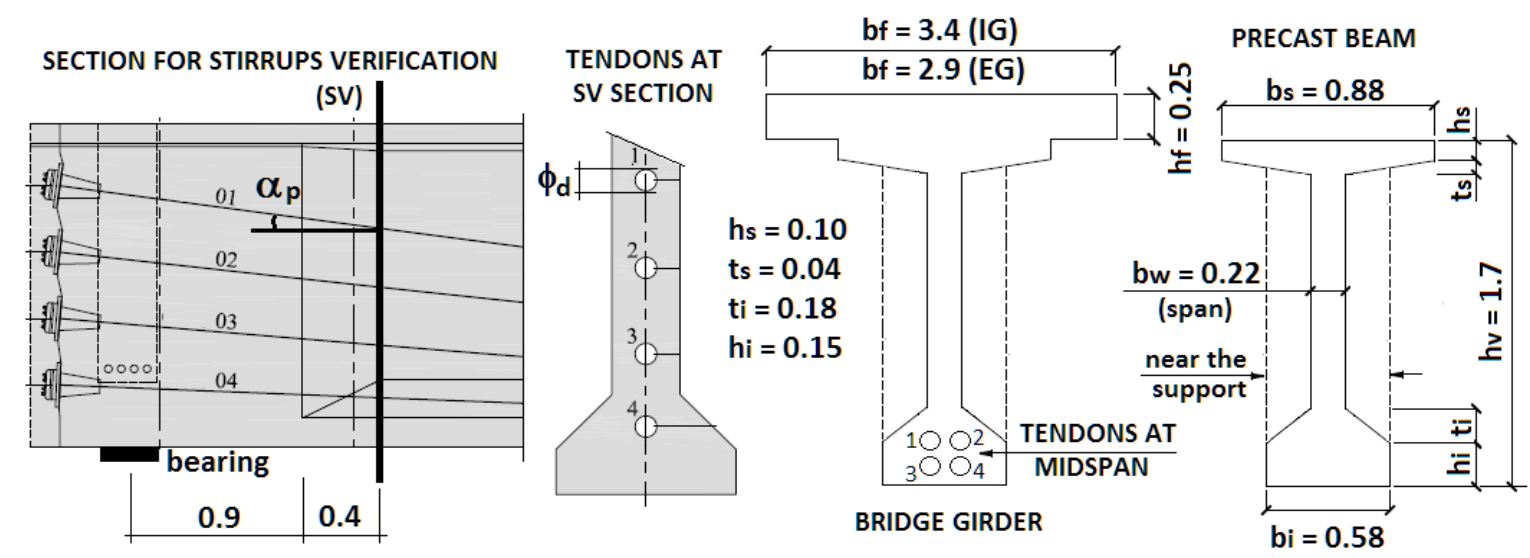

Figure 10. Bridge girder details, dimensions in meters (EG: exterior girder; IG: interior girder).

For complete prestressing, it was found that the longitudinal reinforcing would not be necessary. In this case, the ratio of $0.09 \%$ is used for reinforcing, which corresponds to $0.5 \rho_{\min }$, where $\rho_{\min }$ is the minimum ratio of longitudinal reinforcement (reinforcing and prestressing) for beams recommended by NBR 6118 [15]. The value of $0.5 \rho_{\min }$ was obtained based on the minimum ratio for positive reinforcing in one-way prestressed slabs of NBR 6118 [15], as recommended by IBRACON [40].

Table 5. Reinforcement areas according to prestress levels.

\begin{tabular}{|c|c|c|c|}
\hline Prestress level & Prestressing steel $\left(A_{p}\right)$ & $\begin{array}{c}\text { Longitudinal reinforcing steel } \\
\text { (As) }\end{array}$ & Two-legged stirrup $\left(\mathrm{A}_{\mathrm{sw}} / \mathrm{s}\right)$ \\
\hline Limited & $40 \mathrm{~cm}^{2}\left(40\right.$ strands; $\left.\phi_{\mathrm{p}}=12.7 \mathrm{~mm}\right)$ & $24.13 \mathrm{~cm}^{2}\left(12\right.$ bars; $\left.\phi_{\mathrm{s}}=16 \mathrm{~mm}\right)$ & $\begin{array}{c}14.02 \mathrm{~cm}^{2} / \mathrm{m}\left(\phi_{\mathrm{s}}=12.5 \mathrm{~mm} ; \mathrm{s}=\right. \\
17.5 \mathrm{~cm})\end{array}$ \\
\hline Complete & $48 \mathrm{~cm}^{2}\left(48\right.$ strands; $\left.\phi_{\mathrm{p}}=12.7 \mathrm{~mm}\right)$ & $12.06 \mathrm{~cm}^{2}\left(6 \mathrm{bars} ; \phi_{\mathrm{s}}=16 \mathrm{~mm}\right)$ & $\begin{array}{c}8.98 \mathrm{~cm}^{2} / \mathrm{m}\left(\phi_{\mathrm{s}}=10 \mathrm{~mm} ; \mathrm{s}=\right. \\
17.5 \mathrm{~cm})\end{array}$ \\
\hline
\end{tabular}

Notes: $\mathrm{A}_{\mathrm{sw}}$ : cross-section area of the stirrups; s: longitudinal spacing between the stirrups. 


\subsection{Traffic load effect}

For the transverse load distribution on the girders, the trucks are assumed to be in the center of the traffic lanes and the value of 2 meters is adopted for the transverse wheel spacing, as illustrated in Figure 9. For the longitudinal analysis, the bending moment is calculated at midspan, the shear force and the torsional moment are calculated adjacent to the support, and the influence lines were implemented in Microsoft Excel. To determine the shear force and the torsional moment at the critical section (Figure 10), the load effects obtained by the influence line are linearly reduced.

To consider dynamic amplification, the factor presented in Almeida et al. [41] is used. Using trucks with five and six axles, with a total weight of $450 \mathrm{kN}$, the authors performed dynamic monitoring on Brazilian bridges with spans ranging from 7.5 to 45 meters. Equation 10 presents the obtained dynamic application factor $(D A F)$. For the considered span length, this coefficient varies between 1.11 and 1.37, according to the WIM vehicle speed.

$D A F=1.099+1.439 S_{v}(10)$

where $S_{v}$ : speed parameter (dimensionless); $S_{v}=\pi v /(L \omega) ; v:$ vehicle speed, in $\mathrm{m} / \mathrm{s} ; L:$ span length, in meters; $\omega:$ bridge natural angular frequency, in $\mathrm{rad} / \mathrm{s} ; \omega=2 \pi 95.4 / L^{0.933}$.

The traffic passage along the bridge generates irregular load cycles, with variable frequency and amplitudes, which does not enable straight use of the Palmgren-Miner rule. Then, the Rainflow counting method is used, which makes it possible to obtain individual cycles. Before performing the Rainflow count, however, a computational routine was implemented to obtain the load effects, at the considered sections, due to the traffic passage along the span of the structure. The load effects are obtained both for the single-vehicle passage and multiple presences.

To identify the situation of single and multiple presences, a routine was implemented to the WIM data, in Microsoft Excel spreadsheets, that uses the following information:

- truck travel lane;

- truck speed;

- the time vehicle goes over the sensor (resolution of $0.01 \mathrm{sec}$ );

- the overall length of the vehicle's axle group;

- bridge span length (simply supported structures).

The single passages of the vehicle on the bridge, i.e., when there are no axles of other trucks at the same time on the bridge, present the occurrence of $85 \%$ for the considered span ( $15 \%$ of vehicles are in multiple presence). The "sideby-side" case, i.e., when the front axle spacing between two vehicles, in different lanes, is less than half the length of the axle group of the first vehicle, present the occurrence of $2.35 \%$ in relation to the total valid trucks. Hence, for every 100 trucks on average, one is next to the other.

Using the Rainflow counting procedure and calculating the safety levels, it was found that, except for the side-byside case, the other situations of multiple presences can be replaced, without loss to the analysis, by the individual passage of the vehicles. The results presented in Section 5 are the same when considering the different situations of multiple presences $(15 \%)$ and when considering only the "side-by-side" case $(2.35 \%)$ as multiple presence. This occurs because, except for the side-by-side case, the position of the second vehicle in the other cases of multiple presences, for the considered span, coincides with the lower ordinates of the influence lines. It also applies to the case of three or more vehicles on the bridge. It is essential to observe, however, that for longer span lengths or continuous bridges, other situations of multiple presences might be relevant.

Applying Rainflow and calculating the safety levels, it was also found that the method can be substituted, without loss to the analysis, by the maximum vehicles load effects at the studied sections. The results, presented in Section 5, are the same when using the Rainflow method and when considering only the maximum vehicle load effects in the considered sections. This occurs because, except for the cycles related to the maximum load effects, the other cycles obtained with Rainflow, accumulate irrelevant damages, since they present, in their majority, small load effects in magnitude. It is important to note, however, that for other bridge scenarios, such as continuous structures, for instance, the cycles obtained by Rainflow can be relevant.

With the traffic load effects, the stress range in the reinforcement and the damage for each girder of the bridge are calculated. Overall, the stress range in the reinforcement is determined according to Equation 11, where $\sigma_{\max }$ and $\sigma_{\min }$ are maximum and minimum stresses, respectively.

$\Delta \sigma=\sigma_{\max }-\sigma_{\min }$ 
The equations for calculating the stress range in the reinforcement are presented in the following sections. Although the present paper considers only prestressed girders, the equations also apply to reinforced elements. In this case, it is enough to eliminate the parcels related to prestressing.

\subsection{Stress range in prestressing steel}

For the stress calculation in longitudinal reinforcement, $f i b$ [14] recommends the cracked section to be considered, if for any combination of loads at SLS, cracking occurs. For the girders of the studied bridge, there is cracking due to traffic. Applying Equation 11, the stress range in the prestressed reinforcement, $\Delta \sigma_{\left(A_{p}\right)}$, at stage 2, for the midspan section, is given by Equation 12, where the dimensions of the girders are presented in Figure 10.

$$
\Delta \sigma_{\left(A_{p}\right)}=\frac{M_{q} \cdot x_{2}}{I_{e}} \cdot \frac{\left(d_{p}-x_{2}\right)}{x_{2}} \cdot \frac{E_{p}}{E_{c s}}
$$

where

$M_{q}$ : bending moment at midspan due to each traffic cycle;

$x_{2}$ : neutral axis depth of the section at stage 2 , measured from the compressed face of the section (it is calculated using girder dimensions and reinforcement area);

$d_{p}$ : effective depth related to prestressed reinforcement (distance from the center of gravity of the prestressing steel to the compressed section face);

$E_{p}$ : modulus of elasticity of prestressing steel;

$E_{c s}:$ secant elasticity modulus of concrete;

$I_{e}$ : effective moment of inertia of cracked section (Branson's inertia) at midspan, according to the equation:

$I_{e}=\left(\frac{M_{r}}{M_{s, \max }}\right)^{3} I+\left[I-\left(\frac{M_{r}}{M_{s, \max }}\right)^{3}\right] I_{2} \leq I$

$I$ : Moment of inertia of gross concrete section (it is calculated according to girder dimensions);

$I_{2}$ : moment of inertia of the section at stage 2 (calculated using girder dimensions and reinforcement area);

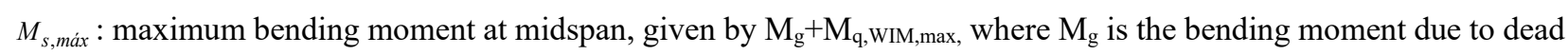

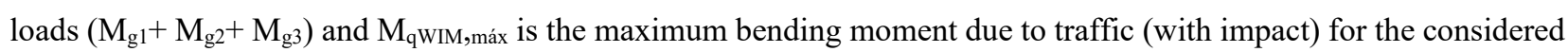
period for the WIM data;

$\mathrm{M}_{\mathrm{g} 1}$ : bending moment at midspan due to the self-weight of the precast beam;

$\mathrm{M}_{\mathrm{g} 2}$ : bending moment at midspan due to the self-weight of the slab and barriers;

$\mathrm{M}_{\mathrm{g} 3}$ : bending moment at midspan due to pavement;

$M_{r}$ : Cracking moment of the section at midspan, calculated based on Equation 14, with absolute values;

$M_{r}=\left(f_{c t, f}+\frac{\left(\sigma_{0 p}-\Delta \sigma_{p}\right) \cdot A_{p}}{A}+\frac{\left(\sigma_{0 p}-\Delta \sigma_{p}\right) \cdot A_{p} \cdot e_{p} \cdot y_{i n f}}{I}\right) \cdot \frac{I}{y_{i n f}}$

$e_{p}$ : eccentricity of the tendons at midspan section (distance from the center of gravity of the prestressed reinforcement to the center of gravity of gross concrete section; $e_{p}=d_{p}-\left(h_{v}+h_{f}-y_{\text {inf }}\right)$;

$y_{i n f}:$ distance from the bottom face of the section to the center of gravity of gross concrete section (calculated using girder dimensions);

$f_{c t, f}$ : tensile strength of concrete in bending; $f_{c t, f}=0.252 \mathrm{f}_{\mathrm{c}}^{2 / 3}$, for $\mathrm{T}$ sections with $\mathrm{f}_{\mathrm{c}} \leq 50 \mathrm{MPa}\left(\mathrm{f}_{\mathrm{c}}\right.$ is the concrete compressive strength at 28 days, in megapascals); 
$A$ : gross area of concrete section (calculated using girder dimensions);

$A_{p}:$ total area of prestressing reinforcement (all the strands);

$\sigma_{0_{p}}:$ initial stress in prestressing;

$\Delta \sigma_{p}:$ prestress losses.

\subsection{Stress range in longitudinal reinforcing steel}

According to fib [14], the effect of differences in bond behavior of prestressing and reinforcing steel must be considered by multiplying the stress in the reinforcing steel by the factor $\eta_{s}$. Thus, the stress range calculation in the longitudinal reinforcing steel, $\Delta \sigma_{\left(A_{s}\right)}$, at stage 2 , for the midspan section, is given by:

$$
\Delta \sigma_{\left(A_{s}\right)}=\frac{M_{q} \cdot x_{2}}{I_{e}} \cdot \frac{\left(d_{s}-x_{2}\right)}{x_{2}} \cdot \frac{E_{s}}{E_{c s}} \cdot \eta_{s}
$$

where

$$
\eta_{s}=\frac{1+\frac{A_{p}}{A_{s}}}{1+\frac{A_{p}}{A_{s}} \cdot \sqrt{\xi_{p} \frac{\phi_{s}}{\phi_{p}}}} \geq 1
$$

$d_{s}$ : effective depth related to reinforcing steel (distance from the center of gravity of the reinforcing steel to the compressed section face);

$A_{s}:$ area of reinforcing steel;

$\phi_{s}:$ diameter of reinforcing steel in the relevant section (the smallest diameter);

$\phi_{p}$ : diameter of prestressing steel (for bundles, an equivalent diameter $\phi_{e q}=1.6 \sqrt{A_{p, b}}$ is chosen, where $A_{p, b}$ is the crosssection area of the bundle);

$E_{s}$ : modulus of elasticity of reinforcing steel;

$\xi_{p}$ : ratio of bond strength of prestressing steel and high-bond reinforcing steel. For strands in post-tensioned members, the value of $\xi_{p}$ is 0.4 .

In NBR 6118 [15], the same factor $\eta_{s}$ is recommended both for reinforcing steel and bonded prestressed steel. In this work, however, it is considered only for the reinforcing steel, according to fib [14].

\subsection{Stress range in stirrups}

Applying Equation 11, the stress range in the stirrups, $\Delta \sigma_{\left(A_{s v} / s\right)}$, for the critical section (Figure 10), is given by Equation 17. As the bridge only have crossbeams on the supports, in addition to the shear force, the torsional moment must also be considered.

$\Delta \sigma_{\left(A_{s w} / s\right)}=\left(\frac{\left|V_{1}-V_{2}\right|}{0.9 d_{s}\left(\frac{A_{s w}}{s}\right)}+\frac{\Delta T}{2 A_{e}\left(\frac{A_{90}}{s}\right)}\right) \sqrt{\tan \theta}$

where

$A_{s w}:$ Cross-sectional area of the stirrups at the section under consideration;

$s$ : longitudinal spacing between the stirrups in the evaluated section; 
$\theta$ : inclination angle of the compression diagonals (struts) regarding the longitudinal axis of the girder (without correction, since the parcel $\sqrt{\tan \theta}$ makes de adjustment in the inclination for fatigue). This angle is 45 degrees for Truss Model I and might vary between 30 to 45 degrees for Truss Model II. In this paper, Model II with a 30-degree angle is considered.

$$
\begin{aligned}
& V_{l}=V_{g}+V_{q}-V_{p}-0.5 V_{c} \geq 0, \text { if }\left(V_{g}+V_{q}-V_{p}\right) \geq 0 \\
& V_{l}=V_{g}+V_{q}-V_{p}+0.5 V_{c} \leq 0, \text { if }\left(V_{g}+V_{q}-V_{p}\right)<0 \\
& V_{2}=V_{g}-V_{p}-0.5 V_{c} \geq 0, \text { if }\left(V_{g}-V_{p}\right) \geq 0 \\
& V_{2}=V_{g}-V_{p}+0.5 V_{c} \leq 0, \text { if }\left(V_{g}-V_{p}\right)<0
\end{aligned}
$$

$\mathrm{V}_{\mathrm{g}}$ : absolute value of the shear force at the section under consideration due to dead loads $\left(\mathrm{V}_{\mathrm{g}}=\mathrm{V}_{\mathrm{g} 1}+\mathrm{V}_{\mathrm{g} 2}+\mathrm{V}_{\mathrm{g} 3}\right)$; $\mathrm{V}_{\mathrm{g} 1}$ : absolute value of the shear force at the section under consideration due to the self-weight of the precast beam; $\mathrm{V}_{\mathrm{g} 2}$ : absolute value of the shear force at the section under consideration due to the self-weight of the slab and barriers; $\mathrm{V}_{\mathrm{g} 3}$ : absolute value of the shear force at the section under consideration due to the pavement;

$\mathrm{V}_{\mathrm{q}}$ : absolute value of the shear force at the section under consideration due to each traffic cycle;

$\mathrm{V}_{\mathrm{p}}$ : absolute value of the shear force at the section under consideration due the prestressing;

$V_{p}=A_{p, b}\left(\sigma_{\sigma_{p}}-\Delta \sigma_{p}\right) \sum \sin \alpha_{p}$

$\alpha_{p}$ : angle of inclination of the tendon in relation to the longitudinal axis of the girders at the section under consideration (Figure 10);

$\mathrm{V}_{\mathrm{c}}$ : parcel of the shear force resisted by the complementary mechanisms of the truss (it is important to note that, as indicated by NBR 6118 [15], a 50\% reduction is considered in $\mathrm{V}_{\mathrm{c}}$ to calculate $\mathrm{V}_{1}$ and $\mathrm{V}_{2}$. In NBR 6118 [42], the reduction was not indicated for Truss Model II).

$\mathrm{V}_{\mathrm{c}}=\mathrm{V}_{\mathrm{c} 0}$, for Model I in reinforced elements (not used in this paper);

$\mathrm{V}_{\mathrm{c}}=\mathrm{V}_{\mathrm{cl}}$, for Model II in reinforced elements (not used in this paper);

$\mathrm{V}_{\mathrm{c}}=\mathrm{V}_{\mathrm{c} 0}\left(1+\mathrm{M}_{0} / \mathrm{M}_{\mathrm{s}, \text { máx }}\right) \leq 2 \mathrm{~V}_{\mathrm{c} 0}$, for Model I in prestressed elements (not used in this paper);

$\mathrm{V}_{\mathrm{c}}=\mathrm{V}_{\mathrm{cl}}\left(1+\mathrm{M}_{0} / \mathrm{M}_{\mathrm{s}, \text { máx }}\right) \leq 2 \mathrm{~V}_{\mathrm{cl}}$, for Model II in prestressed elements;

$\mathrm{V}_{\mathrm{c} 1}=\mathrm{V}_{\mathrm{c} 0}$, when $\mathrm{V}_{\mathrm{s}, \text { máx }} \leq \mathrm{V}_{\mathrm{c} 0}$

$V_{c 1}=\left[\left(V_{R 2}-V_{s, \operatorname{máx}}\right) /\left(V_{R 2}-V_{c 0}\right)\right] \cdot V_{c 0}$, when $V_{s, \operatorname{máx}}>V_{c 0}$

$V_{c 0}=0.6 f_{c t} b_{w, e f} d_{s}$

$\mathrm{V}_{\mathrm{R} 2}$ : shear force strength regarding the diagonal compression failure of concrete;

$V_{R 2}=0.27\left[1-\left(f_{c} / 250\right)\right] f_{c} b_{w, e f} d_{s} \sin (2 \theta)$, with $\mathrm{f}_{\mathrm{c}}$ in $\mathrm{MPa}$;

$\mathrm{V}_{\mathrm{s} \text {,máx }}$ : maximum shear force at the analyzed section, given by $\mathrm{V}_{\mathrm{g}}+\mathrm{V}_{\mathrm{qWIM} \text {,máx }}-\mathrm{V}_{\mathrm{p}}$, where $\mathrm{V}_{\mathrm{qWIM} \text {,máx }}$ is the maximum shear force due to traffic (with impact) for the considered period for the WIM data;

$\mathrm{f}_{\mathrm{ct}}$ : tensile strength of concrete; $\mathrm{f}_{\mathrm{ct}}=0.21 \mathrm{f}_{\mathrm{c}}^{2 / 3}$, to $\mathrm{f}_{\mathrm{c}} \leq 50 \mathrm{MPa}$, with $\mathrm{f}_{\mathrm{c}}$ in MPa;

$b_{w, e f}=b_{w}-0.5 \phi_{d}$, where $\phi_{d}>b_{w} / 8$;

$\phi_{\mathrm{d}}$ : diameter of the prestressing duct (Figure 10). 
Fusco [43] explains that the ratio between the decompression moment $\left(\mathrm{M}_{0}\right)$ and the maximum moment in the region under analysis is a relative measure of the possible cracking degree of the member. Strictly speaking, the author elucidates that the decompression moment could be substituted by the cracking moment $M_{r}$ (Equation 14). Thereby,

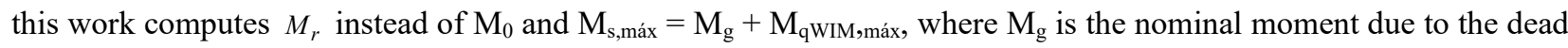
loads $\left(\mathrm{M}_{\mathrm{g} 1}+\mathrm{M}_{\mathrm{g} 2}+\mathrm{M}_{\mathrm{g} 3}\right)$ and $\mathrm{M}_{\mathrm{qWIM} \text {,máx }}$, is the maximum moment due to traffic (with impact), all referring to midspan.

Regarding torsion, the variation of torsional moment $\Delta T$ assumes an absolute value of $T_{\mathfrak{q}}$, as long as there is no inversion in the direction between $\left(\mathrm{T}_{\mathrm{g}}+\mathrm{T}_{\mathrm{q}}\right)$ and $\mathrm{T}_{\mathrm{g}}$. In the case of an inversion, $\Delta T$ is given by the highest absolute value between $\left(T_{g}+T_{q}\right)$ e $T_{g}$.

$\mathrm{T}_{\mathrm{q}}$ : torsional moment at the section under consideration from the traffic, associated with $\mathrm{V}_{\mathrm{q}}$;

$T_{\mathrm{g}}$ : torsional moment at the section under consideration due to the dead loads $\left(T_{\mathrm{g}}=\mathrm{T}_{\mathrm{g} 1}+\mathrm{T}_{\mathrm{g} 2}+\mathrm{T}_{\mathrm{g} 3}\right)$;

$\mathrm{T}_{\mathrm{g} 1}$ : torsional moment at the section under consideration due to the self-weight of the precast beams;

$\mathrm{T}_{\mathrm{g} 2}$ : torsional moment at the section under consideration due to the self-weight of the slab and barriers;

$\mathrm{T}_{\mathrm{g} 3}$ : torsional moment at the section under consideration due to the pavement;

$A_{e}$ : area enclosed by the centerlines of the wall of the equivalent hollow section, including inner hollow areas (section composed by rectangles as indicated in Stucchi and Skaf [39]). It is calculated according to girder dimensions, considering $\mathrm{h}_{\mathrm{e}}=10.5 \mathrm{~cm}$;

$h_{e}$ : wall thickness of the equivalent hollow section $\left(2 c_{1} \leq h_{e} \leq A / u_{p}\right)$;

$\mathrm{c}_{1}$ : distance between the axis of the longitudinal corner rebar and the lateral face of the section;

A: total area of the cross-section (gross area of concrete);

$\mathrm{u}_{\mathrm{p}}$ : perimeter of cross-section;

$A_{90}$ : reinforcement area, perpendicular to the axis of the beam, contained in the equivalent wall. For the section under consideration, $A_{90}=A_{s w} / 2$ (two-legged stirrup).

\section{FATIGUE-SAFETY ASSESSMENT}

In this paper, fatigue safety is assessed for different traffic volumes. For the studied WIM station, the Average Daily Truck Traffic (ADTT) for two lanes is 3655 . It is worth noting that the ADTT computes only heavy vehicles, according to the filter criteria presented. For fatigue-safety assessment, Rodrigues et al. [7] used ADTT $=5000$ and CrespoMinguillón and Casas [6] used ADTT $=6000$ (both for two traffic lanes). Wassef et al. [8] used ADTT $=5000$. The present paper assesses fatigue safety for three ADTT: 2500, 5000 and 7500. The correction in the traffic volume, therefore, is made by multiplying the damage calculated for the WIM traffic by the ratio ADTT/3655.

All results presented in this Section correspond to bridge girders designed following NBR 6118 [15]. The reliability indexes and fatigue life estimates for stirrups are evaluated using S-N curves for straight bars, as justified by several studies (Section 2.2).

\subsection{Fatigue service life estimation}

For the damage calculation (Equation 2), related to fatigue service life estimation, the S-N curves from fib [14] are utilized, as indicated in Table 1 (characteristic values), where all the variables are computed with deterministic values. The concrete strength under shear force is considered with $f_{c t}=f_{c t d}$, where $f_{c t d}=0.15 f_{c k}{ }^{2 / 3}$. The calculated damage is extrapolated for a year-period, considering the correction in ADTT and with Equation (3) the values for fatigue life of the girders are estimated.

Based on the Palmgren-Miner model, Jacob and Labry [44] explain that the estimates below 50 years are not adequate for a bridge project, estimates between 50 and a few hundred years can be considered as acceptable or good and estimates greater than 1000 years indicate unlimited fatigue life. These indicators, however, are only preliminary, since the conclusion about fatigue safety should be based, mainly, on the reliability indexes (probabilistic analysis performed in the next Section). This because even if the analysis considers the real spectrum of vehicles traveling over a bridge, the fatigue life calculation is based on deterministic values (characteristic S-N curves; characteristic concrete strength; $D M=1$; nominal values for dead loads, reinforcement areas and elements dimensions), which, in reality, present variability.

The fatigue life estimation was performed for all girders. The estimates of longitudinal reinforcements (midspan section) and stirrups (section indicated in Figure 10) of all girders, for all ADTT considered, were found to be higher than 1000 years for both limited and complete prestressing, which indicates infinite fatigue life. 


\subsection{Reliability indexes}

In literature, different values are observed for the target reliability index $\left(\beta_{t}\right)$ for fatigue. Aspects such as consequences of failures, inspection, repair possibility or reference period may influence the choice of $\beta_{t}$. For a reference period of 50 years, fib [45] proposes $\beta_{t}=3.1$ for the calibration of the partial safety factors for fatigue. For the same reference period, ISO 13822 [46] indicates $\beta_{t}=2.3$ in the case of the possibility of inspecting the member subjected to fatigue and $\beta_{t}=3.1$, in the case of no inspection possibility. Thus, the reinforcement in the concrete structures fits in $\beta_{t}=3.1$, as stated by $f i b$ [45]. It is worth to mention that $f i b$ [45] recommends $\beta_{t}=3.8$ for ULS, corresponding to medium consequences of failure, and $\beta_{t}=1.5$ for SLS, corresponding to irreversible service failure. According to the model code, the value of $\beta_{t}=3.1$ for fatigue corresponds to the ULS assessment in the case of low consequence of failure. For the unlimited fatigue life approach, which is not the case of the present paper, Wassef et al. [8] indicates $\beta_{t}=1.0$.

The reliability indexes of the girders are calculated by evaluation of the limit state function, according to Equation 9, for the longitudinal reinforcement (midspan section) and stirrups (section indicated in Figure 10), for the design service life of 50 years (compatible with the reference period of $\beta_{t}$ from $f i b$ [45]). The reliability indexes are calculated for the girders that presented the highest values of $\sum\left(1 / \mathrm{N}_{\mathrm{i}}\right)$, related to the longitudinal and transverse reinforcement.

The random variables are presented in Table 6, where some of them are Brazilian statistics, as reported by Santiago [25], [26] and Santiago et al. [47], [48]. Other variables consider the statistics utilized in Nowak [27] and Wassef et al. [8]. The statistics for the dead load, obtained from Nowak [27], are computed in this work directly in the loads, i.e., the span length is considered as deterministic. Variables from Section 4 which are not indicated in Table 6 are considered as deterministic. For each random variable, related to longitudinal or transverse reinforcement, 50 values are generated by using the Latin Hypercube Sampling - LHS simulation technique. Crespo-Minguillón and Casas [6] also considers this number of simulations using LHS.

Table 6. Random variables (indicated in Figure 10 and Section 4).

\begin{tabular}{|c|c|c|c|c|c|}
\hline Category & Variable & Distribution & Mean / Nominal & $C V^{1}$ & Remarks \\
\hline \multirow{8}{*}{$\begin{array}{c}\text { Material } \\
\text { characteristics }\end{array}$} & $\mathrm{f}_{\mathrm{c}}\left(\mathrm{f}_{\mathrm{ck}}=40 \mathrm{MPa}\right)$ & Normal & 1.16 & 0.11 & Santiago [25] \\
\hline & $E_{\mathrm{cs}}$ & Normal & 1.04 & 0.04 & Santiago [26] \\
\hline & $\mathrm{E}_{\mathrm{p}}$ & Normal & 1.03 & 0.02 & Santiago [26] \\
\hline & $\mathrm{E}_{\mathrm{s}}$ & Normal & 1.03 & 0.02 & $\mathrm{E}_{\mathrm{p}}$ \\
\hline & $A_{p}, A_{p, b}$ & Lognormal & 1.03 & 0.01 & Santiago [25] \\
\hline & $\mathrm{A}_{\mathrm{s}}, \mathrm{A}_{\mathrm{sw}}$ & Lognormal & 1.03 & 0.01 & $A_{p}$ \\
\hline & $\sigma_{0 \mathrm{p}}$ & Normal & 0.97 & 0.08 & Used in Wassef et al. [8] $]^{2}$ \\
\hline & $\Delta \sigma_{\mathrm{p}}$ & Normal & 1.05 & 0.10 & Used in Wassef et al. $[8]^{3}$ \\
\hline \multirow{4}{*}{$\begin{array}{l}\text { Girder geometric } \\
\text { data }\end{array}$} & $b_{s}, b_{w}, b_{i}, b_{f}$ & Normal & 1.00 & 0.04 & Used in Wassef et al. [8] \\
\hline & $\mathrm{h}_{\mathrm{v}}, \mathrm{h}_{\mathrm{f}}, \mathrm{h}_{\mathrm{s}}, \mathrm{h}_{\mathrm{i}}$ & Normal & 1.00 & 0.025 & Used in Wassef et al. [8] \\
\hline & $\mathrm{t}_{\mathrm{s}}, \mathrm{t}_{\mathrm{i}}$ & Normal & 1.00 & 0.025 & $\mathrm{~h}_{\mathrm{s}}, \mathrm{h}_{\mathrm{i}}$ \\
\hline & $\mathrm{d}_{\mathrm{p}}, \mathrm{d}_{\mathrm{s}}$ & Normal & 1.00 & 0.04 & Used in Wassef et al. [8] \\
\hline \multirow{3}{*}{$\begin{array}{l}\text { Load effect for dead } \\
\text { loads }\end{array}$} & $\mathrm{M}_{\mathrm{g} 1}, \mathrm{~V}_{\mathrm{g} 1}, \mathrm{~T}_{\mathrm{g} 1}$ & Normal & 1.03 & 0.08 & Nowak [27] \\
\hline & $\mathrm{M}_{\mathrm{g} 2}, \mathrm{~V}_{\mathrm{g} 2}, \mathrm{~T}_{\mathrm{g} 2}$ & Normal & 1.05 & 0.10 & Nowak [27] \\
\hline & $\mathrm{M}_{\mathrm{g} 3}, \mathrm{~V}_{\mathrm{g} 3}, \mathrm{~T}_{\mathrm{g} 3}$ & Normal & 1.10 & 0.25 & Nowak [27] \\
\hline
\end{tabular}

Note 1: CV is the coefficient of variation (standard deviation/mean) Note 2: From Gross and Burns [28] Note 3: From Gross and Burns [28] and Tadros et al. [29] Note 4: From Naaman and Siriaksorn [30] 
The damage relative to the WIM data is calculated for each simulation, according to the S-N curves indicated in Table 2, and extrapolated for the intended reference period (50 years) considering the correction of ADTT. With the calculated values, the probability distribution, moments, and parameters of the dependent variable $\sum\left(1 / \mathrm{N}_{\mathrm{i}}\right)$ are obtained, which represents the load effect variable in the limit state function (9). The interior girder showed the highest values of $\sum\left(1 / \mathrm{N}_{\mathrm{i}}\right)$ for the stirrups, and the exterior girder (near to rightmost lane) presented the highest values of $\sum\left(1 / \mathrm{N}_{\mathrm{i}}\right)$ for the longitudinal reinforcement.

The damage calculation is performed using Microsoft Excel, while the simulations and parameters obtaining are performed in Matlab. It is found that the $\sum\left(1 / \mathrm{N}_{\mathrm{i}}\right)$ variable fit the Lognormal distribution. Using ADTT $=5000$ and limited prestressing, for example, Figure 11 shows the 50 values of $\sum\left(1 / \mathrm{N}_{\mathrm{i}}\right)$ for stirrups of interior girder in Lognormal probability paper (moments and parameters are indicated in Table 9).

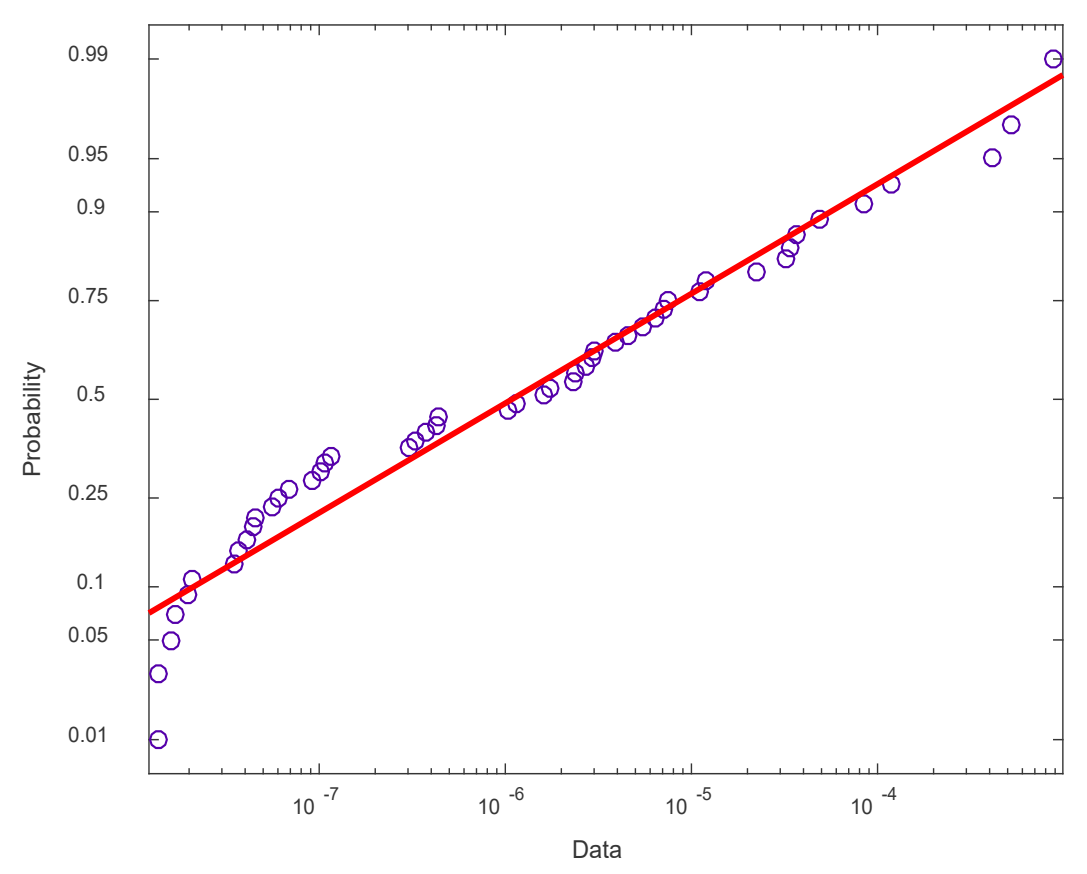

Figure 11. Values of dependent variable $\sum\left(1 / \mathrm{N}_{\mathrm{i}}\right)$ for stirrups in Lognormal probability paper considering limited prestressing and $\mathrm{ADTT}=5000$.

After all simulations for limited and complete prestressing, for all ADTT values considered, it is verified that almost all calculated stress ranges are lower than $205 \mathrm{MPa}$ for reinforcing steel (longitudinal and stirrups) and all stress ranges are lower than $165 \mathrm{MPa}$ for prestressing steel. Therefore, the parameters of $D M$, which is the variable of resistance in the limit state function, can be obtained directly from Table 3 (Weibull distribution) and the procedure presented in Section 2.5, for weighting of $D M_{i}$, does not need to be applied.

Tables 7, 8 and 9 present moments for $\sum\left(1 / \mathrm{N}_{\mathrm{i}}\right)$ and $D M$ according to reinforcement, ADTT and prestress level. Using FORM, and the StRAnD [31] software, the fatigue reliability indexes are obtained, as indicated in Tables 7, 8 and 9. The longitudinal reinforcement (prestressing and reinforcing) and stirrups have shown fatigue reliability indexes higher than the intended value for design $\left(\beta_{t}=3.1\right)$. As expected, the reliability indexes decrease with the increase in traffic volume. The increase in ADTT from 5000 to 7500, however, did not significantly change the results. Complete prestressing presents higher safety levels than limited prestressing for both longitudinal reinforcements and stirrups. Although the Brazilian live load model is not in accordance with the unlimited fatigue life approach, as stated by Carneiro et al. [4], the design criteria, which involve partial safety factors and stress limits for fatigue design, guaranteed satisfactory fatigue safety levels for the evaluated bridge. 
Table 7. Moments for dependent variables and reliability indexes $(\beta)$ for prestressing steel (exterior girder) for design service life of 50 years.

\begin{tabular}{|c|c|c|c|c|c|c|}
\hline \multirow{2}{*}{$\begin{array}{l}\text { ADTT (average } \\
\text { daily truck } \\
\text { traffic) }\end{array}$} & \multirow[b]{2}{*}{ Prestress level } & \multicolumn{2}{|c|}{$\sum\left(\mathbf{1} / \mathbf{N}_{\mathrm{i}}\right)$ - Lognormal } & \multicolumn{2}{|c|}{$D M$ - Weibull } & \multirow[b]{2}{*}{$\boldsymbol{\beta}$} \\
\hline & & Mean & $\begin{array}{l}\text { Standard } \\
\text { deviation }\end{array}$ & Mean & $\begin{array}{l}\text { Standard } \\
\text { deviation }\end{array}$ & \\
\hline \multirow{2}{*}{2500} & Limited & $6.302 \times 10^{-3}$ & $1.516 \times 10^{-2}$ & 1.072 & 0.367 & 4.1 \\
\hline & Complete & $1.233 \times 10^{-3}$ & $1.319 \times 10^{-3}$ & 1.072 & 0.367 & 5.8 \\
\hline \multirow{2}{*}{5000} & Limited & $1.260 \times 10^{-2}$ & $3.031 \times 10^{-2}$ & 1.072 & 0.367 & 3.7 \\
\hline & Complete & $2.464 \times 10^{-3}$ & $2.636 \times 10^{-3}$ & 1.072 & 0.367 & 5.4 \\
\hline \multirow{2}{*}{7500} & Limited & $1.891 \times 10^{-2}$ & $4.550 \times 10^{-2}$ & 1.072 & 0.367 & 3.4 \\
\hline & Complete & $3.697 \times 10^{-3}$ & $3.954 \times 10^{-3}$ & 1.072 & 0.367 & 5.2 \\
\hline
\end{tabular}

It is important to mention that according to EN 1992-2 [49], a fatigue design verification is generally not necessary for prestressing and longitudinal reinforcing steel, in regions where, under the frequent combination of actions (including prestressing) only compressive stresses occur at the extreme concrete fibres (like complete prestressing of NBR 6118 [15]). The high reliability indexes for complete prestressing from Tables 7 and 8 for longitudinal reinforcements confirm the EN 1992-2 [49] consideration.

Table 8. Moments for dependent variables and reliability indexes $(\beta)$ for reinforcing steel (exterior girder) for design service life of 50 years.

\begin{tabular}{|c|c|c|c|c|c|c|}
\hline \multirow{2}{*}{$\begin{array}{l}\text { ADTT (average } \\
\text { daily truck } \\
\text { traffic) }\end{array}$} & \multirow[b]{2}{*}{ Prestress level } & \multicolumn{2}{|c|}{$\sum\left(1 / \mathbf{N}_{\mathrm{i}}\right)$ - Lognormal } & \multicolumn{2}{|c|}{$D M$ - Weibull } & \multirow[b]{2}{*}{$\boldsymbol{\beta}$} \\
\hline & & Mean & $\begin{array}{l}\text { Standard } \\
\text { deviation }\end{array}$ & Mean & $\begin{array}{l}\text { Standard } \\
\text { deviation }\end{array}$ & \\
\hline \multirow{2}{*}{2500} & Limited & $1.247 \times 10^{-3}$ & $1.271 \times 10^{-2}$ & 1.169 & 0.618 & 4.0 \\
\hline & Complete & $7.825 \times 10^{-4}$ & $1.803 \times 10^{-3}$ & 1.169 & 0.618 & 4.6 \\
\hline \multirow{2}{*}{5000} & Limited & $2.494 \times 10^{-3}$ & $2.544 \times 10^{-2}$ & 1.169 & 0.618 & 3.7 \\
\hline & Complete & $1.565 \times 10^{-3}$ & $3.608 \times 10^{-3}$ & 1.169 & 0.618 & 4.3 \\
\hline \multirow{2}{*}{7500} & Limited & $3.740 \times 10^{-3}$ & $3.812 \times 10^{-2}$ & 1.169 & 0.618 & 3.5 \\
\hline & Complete & $2.348 \times 10^{-3}$ & $5.412 \times 10^{-3}$ & 1.169 & 0.618 & 4.1 \\
\hline
\end{tabular}

Table 9. Moments for dependent variables and reliability indexes $(\beta)$ for stirrups (interior girder) for design service life of 50 years.

\begin{tabular}{|c|c|c|c|c|c|c|}
\hline \multirow{2}{*}{$\begin{array}{l}\text { ADTT (average } \\
\text { daily truck } \\
\text { traffic) }\end{array}$} & \multirow[b]{2}{*}{ Prestress level } & \multicolumn{2}{|c|}{$\sum\left(\mathbf{1} / \mathbf{N}_{\mathrm{i}}\right)$ - Lognormal } & \multicolumn{2}{|c|}{$D M$ - Weibull } & \multirow[b]{2}{*}{$\boldsymbol{\beta}$} \\
\hline & & Mean & $\begin{array}{l}\text { Standard } \\
\text { deviation }\end{array}$ & Mean & $\begin{array}{l}\text { Standard } \\
\text { deviation }\end{array}$ & \\
\hline \multirow{2}{*}{2500} & Limited & $6.108 \times 10^{-5}$ & $6.874 \times 10^{-3}$ & 1.169 & 0.618 & 4.6 \\
\hline & Complete & $5.512 \times 10^{-5}$ & $3.472 \times 10^{-4}$ & 1.169 & 0.618 & 5.3 \\
\hline \multirow{2}{*}{5000} & Limited & $1.224 \times 10^{-4}$ & $1.379 \times 10^{-2}$ & 1.169 & 0.618 & 4.4 \\
\hline & Complete & $1.102 \times 10^{-4}$ & $6.945 \times 10^{-4}$ & 1.169 & 0.618 & 5.0 \\
\hline \multirow{2}{*}{7500} & Limited & $1.832 \times 10^{-4}$ & $2.062 \times 10^{-2}$ & 1.169 & 0.618 & 4.3 \\
\hline & Complete & $1.654 \times 10^{-4}$ & $1.042 \times 10^{-3}$ & 1.169 & 0.618 & 4.9 \\
\hline
\end{tabular}




\section{CONCLUSIONS}

This work assessed the fatigue safety level provided by Brazilian design standards for a concrete highway bridge, using weigh-in-motion (WIM) data of an important federal Brazilian highway. The fatigue service life and fatigue reliability indexes for design life (50 years) were evaluated for prestressed girders. Using limited and complete prestressing levels, different traffic volumes were considered.

It was found that multiple presence trucks can be safely replaced by the analysis of individual trucks, except for side-by-side truck case. In addition, the Rainflow cycle method can be replaced by the maximum vehicles load effects. The design of longitudinal reinforcements (reinforcing and prestressing) and stirrups according to Brazilian codes ensured fatigue reliability indexes higher than values recommended by fib [45], that is, given the design conditions, it is unlikely that these reinforcements will fail due to fatigue. All fatigue life estimates exceeded 1000 years, which indicates unlimited fatigue life. Although the Brazilian live load model does not comply with the unlimited fatigue life approach, as stated by Carneiro et al. [4], the partial safety factors and stress limits for fatigue design guaranteed satisfactory fatigue safety levels for the evaluated bridge. It is important that the methodology presented in this paper be applied to a greater number of concrete bridges, to provide more general assessment of fatigue safety levels provided by Brazilian design standards.

\section{ACKNOWLEDGEMENTS}

This study has been co-sponsored by CNPq, CAPES, Arteris S.A. and ANTT. The authors gratefully acknowledge the support of this research.

\section{REFERENCES}

[1] Associação Brasileira de Normas Técnicas, Carga Móvel Rodoviária e de Pedestres em Pontes, Viadutos, Passarelas e Outras Estruturas, NBR 7188, 2013.

[2] W. Pfeil, Pontes em Concreto Armado. Rio de Janeiro, R.J.: Livros Técnicos e Científicos, 1979.

[3] Associação Brasileira de Normas Técnicas, Ações e Segurança nas Estruturas - Procedimento, NBR 8681, 2003.

[4] A. L. Carneiro, E. L. Portela, and T. N. Bittencourt, "Development of Brazilian highway live load model for unlimited fatigue life," Rev. IBRACON Estrut. Mater., vol. 13, no. 4, pp. e13407, 2020, http://dx.doi.org/10.1590/S1983-41952020000400007.

[5] E. L. Portela, "Analysis and development of a live load model for Brazilian concrete bridges based on WIM data," Ph.D. dissertation, Polytech. Sch., Univ. São Paulo, São Paulo, Brasil, 2018. Accessed: Apr. 15, 2020. [Online]. Available: https://www.teses.usp.br/teses/disponiveis/3/3144/tde-11122018-151658/pt-br.php

[6] C. Crespo-Minguillón and J. R. Casas, "Fatigue reliability analysis of prestressed concrete bridges," J. Struct. Eng., vol. 124, no. 12, pp. 1458-1466, 1998.

[7] J. F. S. Rodrigues, J. R. Casas, and P. A. O. Almeida, "Fatigue-safety assessment of reinforced concrete (RC) bridges: application to the Brazilian highway network," Struct. Infrastruct. Eng., vol. 9, no. 6, pp. 601-616, 2013, http://dx.doi.org/10.1080/15732479.2011.598939.

[8] W. G. Wassef et al., Calibration of AASHTO LRFD Concrete Bridge Design Specifications for Serviceability, NCHRP Project 12-83. Washington, DC: National Academy of Sciences, 2014. Accessed: Apr. 15, 2020. [Online]. Available: :

https://www.nap.edu/catalog/22407/calibration-of-aashto-lrfd-concrete-bridge-design-specifications-for-serviceability

[9] D. Yan et al., "Lifetime fatigue reliability evaluation of short to medium span bridges under site-specific stochastic truck loading," Adv. Mech. Eng., vol. 9, no. 3, pp. 1-12, 2017, http://dx.doi.org/10.1177/1687814017695047.

[10] P. Junges, "Análise de fadiga em pontes curtas de concreto armado a partir de dados de sistemas B-WIM," Ph.D. dissertation, Univ. Fed. Sta. Catarina, Florianópolis, SC, Brasil, 2017.

[11] C. S. Wang et al., "Fatigue reliability assessment method for concrete girder bridges," in Proc. Int. Conf. on Maintenance, Monitoring, Safety, Risk and Resilience of Bridges and Bridge Networks, IABMAS, 2016.

[12] A. Mankar et al., "Probabilistic reliability framework for assessment of concrete fatigue of existing RC bridge deck slabs using data from monitoring," Eng. Struct., vol. 201, no. 109788, pp. 1-11, 2019, http://dx.doi.org/10.1016/j.engstruct.2019.109788.

[13] A. Mankar, S. Rastayesh, and J. D. Sorensen, "Fatigue Reliability analysis of Cret De l'Anneau Viaduct: a case study," Struct. Infrastruct. Eng., vol. 16, no. 4, pp. 762-771, 2020, http://dx.doi.org/10.1080/15732479.2019.1633361.

[14] Fédération Internationale du Béton, vol. 2, Model Code 2010. Lausanne, Suiça: FIB, 2010.

[15] Associação Brasileira de Normas Técnicas, Projeto de Estruturas de Concreto - Procedimento, NBR 6118, 2014.

[16] European Committee for Standardization, Eurocode 2: Design of concrete structures - Part 1-1: General rules and rules for buildings, EN 1992-1-1, 2004. 
[17] M. Plos et al., Non-Linear Analysis and Remaining Fatigue Life of Reinforced Concrete Bridges. Background Document D4.5 (Sustainable Bridges, Assessment for Future Traffic Demands and Longer Lives). Bruxelas, Bélgica: European Commission, 2007.

[18] C. Higgins et al., "High-cycle fatigue of diagonally cracked RC bridge girders: laboratory tests," J. Bridge Eng., vol. 12, no. 2, pp. 226-236, 2007, http://dx.doi.org/10.1061/(ASCE)1084-0702(2007)12:2(226).

[19] C. Higgins et al., Assessment Methodology for Diagonally Cracked Reinforced Concrete Deck Girders (Final Report, SPR 350-SR 500-91). Washington, D.C.: Oregon Department of Transportation, Federal Highway Administration, 2004.

[20] P. M. Bachman, M. E. Kreger, and J. E. Breen, An Exploratory Investigation of Shear Fatigue Behavior of Prestressed Concrete Girders (Research Report, 465-1). Austin, Texas: Center for Transportation Research, The University of Texas at Austin, 1987.

[21] C. Souza et al., "Fatigue analysis of box-girder webs subjected to in-plane shear and transverse bending induced by railway traffic," Eng. Struct., vol. 54, pp. 248-261, 2013, http://dx.doi.org/10.1016/j.engstruct.2013.04.008.

[22] M. Hillebrand and J. Hegger, "Fatigue testing of shear reinforcement in prestressed concrete t-beams of bridges," Appl. Sci. (Basel), vol. 10, no. 16, pp. 5560, 2020, http://dx.doi.org/10.3390/app10165560.

[23] M. Hillebrand, F. Teworte, and J. Hegger, "Shear fatigue of prestressed I-beams with shear reinforcement," Struct. Concr., pp. 1-15, 2020, http://dx.doi.org/10.1002/suco.202000187.

[24] R. E. Melchers and A. T. Beck, Structural Reliability Analysis and Prediction, 3rd ed. London: Wiley, 2018.

[25] W. C. Santiago, "Calibração baseada em confiabilidade dos coeficientes parciais de segurança das principais normas brasileiras de projeto estrutural", Doctoral dissertation, Univ. S. Paulo, São Carlos, SP, Brasil, 2019.

[26] W. C. Santiago, Calibração baseada em confiabilidade dos coeficientes parciais de segurança de normas brasileiras de projeto estrutural (Texto do exame de qualificação). São Carlos, SP: Universidade de São Paulo, 2017.

[27] A. S. Nowak, Calibration of the LRFD Bridge Design Code (NCHRP Report, 368). Washington, D.C.: Transportation Research Board, National Research Council, 1999.

[28] S. Gross and N. Burns, Field Performance of Prestressed High Performance Concrete Highway Bridges in Texas (Research Report, 9-580/589-2). Austin, Texas: Texas Department of Transportation, Center for Transportation Research, University of Texas at Austin, 2000 .

[29] M. Tadros et al., Prestress Losses in Pretensioned High-Strength Concrete Bridge Girders (NCHRP Report, 496). Washington, DC: Transportation Research Board of the National Academies, 2003.

[30] A. E. Naaman and A. Siriaksorn, "Reliability of partially prestressed beams at serviceability limit states," PCIJ., vol. 27, no. 6, pp. 66-85, 1982.

[31] A. T. Beck, "StRAnD - Structural Reliability Analysis and Design: manual do usuário", São Carlos, SP, Brasil: USP, 2008.

[32] A. Nowak and K. Collins, Reliability of Structures. New York, NY, USA: McGraw-Hill, 2013.

[33] Agência Nacional de Transportes Terrestres. Desenvolvimento do Modelo de Deterioração de Pavimentos Asfálticos com Uso de Instrumentação e Sistema Weigh in Motion (Relatório final). Brasília, D.F.: ANTT, 2016.

[34] A. C. R. Laranjeiras "Fadiga das estruturas de concreto," in An. II Simp. EPUSP Estrut. Concr., São Paulo, SP, Brasil, 1990.

[35] Departamento Nacional de Infraestrutura de Transportes. Quadro de Fabricantes de Veículos. Brasília, DF: Ministério dos Transportes, 2005.

[36] Departamento Nacional de Infraestrutura de Transportes. Quadro de Fabricantes de Veículos. Versão 4.1. Brasília, DF: Ministério dos Transportes, 2007.

[37] Departamento Nacional de Infraestrutura de Transportes. Quadro de Fabricantes de Veículos. Brasília, D.F.: Ministério dos Transportes, 2009.

[38] L. F. Martha, Ftool: Interactive-Graphics Program for Structural Analysis. Version 4.00. 2018. Accessed: Apr. 15, 2020. [Online]. Available: https://webserver2.tecgraf.puc-rio.br/ftool

[39] F. R. Stucchi and K. J. Skaf, Pontes e Grandes Estruturas: Projeto de Superestrutura em Concreto Protendido. São Paulo, SP: Escola Politécnica, Universidade de São Paulo, 2006.

[40] Instituto Brasileiro do Concreto, Comentários e Exemplos de aplicação, ABNT NBR 6118:2014, 2015.

[41] P. A. O. Almeida, J. F. S. Rodrigues, and A. B. Lima, Critérios de Otimização de Projetos de Pontes a Partir de Espectros de Aceleração Induzidas por Veículos nos Tabuleiros. São Paulo, SP: LSE, 2010.

[42] Associação Brasileira de Normas Técnicas, Projeto de Estruturas de Concreto - Procedimento, NBR 6118, 2003.

[43] P. B. Fusco, Estruturas de Concreto: Solicitações Tangenciais. Pini Ltda, São Paulo, 2008.

[44] B. Jacob and D. Labry, "Evaluation of the effects of heavy vehicles on bridges: fatigue,", in 7th International symposium on heavy vehicle weights \& dimensions, Delft, 2002.

[45] Fédération Internationale du Béton, vol. 1, Model Code 2010. Lausanne, Suiça: FIB, 2012.

[46] International Organization for Standardization. Bases for Design of Structures - Assessment of Existing Structures, ISO 13822, 2010. 
[47] W. C. Santiago, H. M. Kroetz, and A. T. Beck, "Reliability-based calibration of Brazilian structural design codes used in the design of concrete structures," Rev. IBRACON Estrut. Mater., vol. 12, no. 6, 2019. http://dx.doi.org/10.1590/s1983-41952019000600004.

[48] W. C. Santiago et al., "Reliability-based calibration of main Brazilian structural design codes," Lat. Am. J. Solids Struct., vol. 17, no. 1, pp. e245, 2020, http://dx.doi.org/10.1590/1679-78255754.

[49] European Committee for Standardization, Eurocode 2: Design of Concrete Structures - Part 2: Concrete Bridges - Design and detailing rules, EN 1992-2, 2005.

Author contributions: ALC: conceptualization, methodology, formal analysis, writing, proofreading; ELP: data curation, writing review, proofreading; TNB: data curation, funding acquisition, supervision, proofreading; ATB: formal analysis, writing review, proofreading.

Editors: Mauro Real, Guilherme Aris Parsekian. 